\title{
Selective Actions of Novel Allosteric Modulators Reveal Functional Heteromers of Metabotropic Glutamate Receptors in the CNS
}

\author{
Shen Yin, ${ }^{1,2}$ Meredith J. Noetzel, ${ }^{1,2}$ Kari A. Johnson, ${ }^{1,2}$ Rocio Zamorano, ${ }^{1,2}$ Nidhi Jalan-Sakrikar, ${ }^{1,2}$ Karen J. Gregory, ${ }^{1,2,3}$ \\ P. Jeffrey Conn, ${ }^{1,2}$ and Colleen M. Niswender ${ }^{1,2}$ \\ ${ }^{1}$ Department of Pharmacology and the ${ }^{2}$ Vanderbilt Center for Neuroscience Drug Discovery, Vanderbilt University Medical Center, Nashville, Tennessee \\ 37232, and ${ }^{3}$ Drug Discovery Biology, Monash Institute of Pharmaceutical Sciences, Monash University, Parkville, Victoria 3052, Australia
}

Metabotropic glutamate (mGlu) receptors play important roles in regulating CNS function and are known to function as obligatory dimers. Although recent studies have suggested heterodimeric assembly of mGlu receptors in vitro, the demonstration that distinct mGlu receptor proteins can form heterodimers or hetero-complexes with other mGlu subunits in native tissues, such as neurons, has not been shown. Using biochemical and pharmacological approaches, we demonstrate here that $\mathrm{mGlu}_{2}$ and $\mathrm{mGlu}_{4}$ form a hetero-complex in native rat and mouse tissues which exhibits a distinct pharmacological profile. These data greatly extend our current understanding of mGlu receptor interaction and function and provide compelling evidence that mGlu receptors can function as heteromers in intact brain circuits.

\section{Introduction}

The metabotropic glutamate (mGlu) receptors are members of the Family C Seven Transmembrane Spanning/G-ProteinCoupled Receptors (7TMRs/GPCRs) and are activated by the major excitatory neurotransmitter, glutamate. In their simplest context, Group I mGlus $\left(\mathrm{mGlu}_{1}\right.$ and $\mathrm{mGlu}_{5}$ ) primarily modulate postsynaptic neuronal activity, whereas the Group II mGlus $\left(\mathrm{mGlu}_{2}\right.$ and $\left.\mathrm{mGlu}_{3}\right)$ are found in both presynaptic and postsynaptic locations, and the Group III receptors $\left(\mathrm{mGlu}_{4}, \mathrm{mGlu}_{6}\right.$, $\mathrm{mGlu}_{7}$, and $\mathrm{mGlu}_{8}$ ) are predominantly expressed presynaptically, where they act as autoreceptors and heteroreceptors to regulate neurotransmitter release (for review, see Niswender and Conn, 2010). The eight mGlu receptor subtypes have been historically thought to function as homodimers (Romano et al., 1996; Kunishima et al., 2000). However, recent in vitro studies suggest that mGlu receptors can also form heterodimers (Doumazane et al., 2011; Kammermeier, 2012), with Group I mGlus interacting with each other but not associating with other

Received March 14, 2013; revised 0ct. 14, 2013; accepted Nov. 8, 2013.

Author contributions: S.Y., M.J.N., K.A.J., N.J.-S., K.J.G., P.J.C., and C.M.N. designed research; S.Y., M.J.N., K.A.J., R.Z., and N.J.-S. performed research;S.Y., M.J.N., K.A.J., N.J.-S., K.J.G., and C.M.N. analyzed data; S.Y., M.J.N., K.A.J., K.J.G., P.J.C., and C.M.N. wrote the paper.

This work was supported by NIH Grants NS048334 (C.M.N. and P.J.C.), NS078262 (C.M.N.), NS031373 (P.J.C.), NS067737 (K.A.J.), NS071746 (M.J.N.), an National Health and Medical Research Council (Australia) Overseas Biomedical Postdoctoral fellowship (K.J.G.), and a National Alliance for Research on Schizophrenia and Depression Maltz Young Investigator Award (K.J.G.). We thank Dr. Corey R. Hopkins, Dr. Darren Engers, and Patrick Gentry for the synthesis of mGlu $_{4}$ PAMs used in this study.

M.J.N., P.J.C., and C.M.N. received research support from Bristol Myers Squibb and Astra Zeneca. The remaining authors declare no competing financial interests.

Correspondence should be addressed to Dr. Colleen M. Niswender, 12478C MRB IV, Department of Pharmacology, Vanderbilt Center for Neuroscience Drug Discovery, Vanderbilt University, Nashville, TN 37232-0697. E-mail: Colleen.niswender@vanderbilt.edu.

DOI:10.1523/JNEUROSCI.1129-13.2014

Copyright $\odot 2014$ the authors $\quad 0270-6474 / 14 / 340079-16 \$ 15.00 / 0$ subtypes, and members of Group II and III receptors coassembling in vitro.

Among the Group III mGlu receptors, $\mathrm{mGlu}_{4}$ plays an important role in the basal ganglia, a primary site of pathology in movement disorders such as Parkinson's disease (PD). Activation of $\mathrm{mGlu}_{4}$ reduces transmission at synapses that project from the striatum to the globus pallidus (striatopallidal synapses) as well as synapses between the subthalamic nucleus and the substantia nigra pars compacta (STN-SNc synapses) (Marino et al., 2003; Valenti et al., 2003, 2005), two synapses that are overactive in PD. At each of these synapses, the response to the general Group III mGlu agonist L-AP4 is potentiated by $N$-phenyl-7-(hydroxyimino) cyclopropa $[b]$ chromen-1a-carboxamide (PHCCC) (Marino et al., 2003; Valenti et al., 2005), a positive allosteric modulator (PAM) that is selective for $\mathrm{mGlu}_{4}$. In contrast to findings at the striatopallidal and STN-SNc synapses, we now report the surprising observation that PHCCC is without effect in regulating $\mathrm{mGlu}_{4}$-modulated transmission at synapses between cortex and striatum (corticostriatal synapses).

Previous immunohistochemistry and in situ hybridization studies suggest that $\mathrm{mGlu}_{2}$ and $\mathrm{mGlu}_{4}$ are colocalized in several brain regions (Ohishi et al., 1993, 1995; Neki et al., 1996; Bradley et al., 1999), and $\mathrm{mGlu}_{2}$ is also functionally expressed at corticostriatal synapses (Johnson et al., 2005). We tested the hypothesis that heterodimers of $\mathrm{mGlu}_{2 / 4}$ may display a unique profile in response to selective $\mathrm{mGlu}_{4}$ PAMs and that these mGlu subtypes form hetero-complexes in the striatum. Through evaluation of $\mathrm{mGlu}_{4}$ PAMs from different chemical scaffolds, we show here that hetero-interactions between $\mathrm{mGlu}_{2}$ and $\mathrm{mGlu}_{4}$ differentially impact responses to individual mGlu receptor PAMs and an $\mathrm{mGlu}_{2}$-negative allosteric modulator (NAM). Furthermore, coimmunoprecipitation studies suggest that $\mathrm{mGlu}_{2}$ and $\mathrm{mGlu}_{4}$ re- 
ceptors form hetero-complexes in the striatum and the unique pharmacological profile of effects of selected $\mathrm{mGlu}_{4}$ receptor PAMs, as well as an mGlu ${ }_{2}$ NAM, is recapitulated at the corticostriatal synapse. These studies directly impact our understanding of mGlu receptors and regulation by allosteric modulators in the basal ganglia; providing critical insights into potential functions and pharmacological properties of mGlu receptors that are coexpressed in multiple regions and cell populations.

\section{Materials and Methods}

Cell line establishment and cell culture. Cell culture reagents were purchased from Invitrogen unless otherwise noted. Rat $\mathrm{mGlu}_{2}$ or rat $\mathrm{mGlu}_{4}$ was cloned into the pIRESpuro3 vector, transfected into human embryonic kidney (HEK)/G-protein inwardly rectifying potassium (GIRK) cells, and selected with puromycin. Polyclonal rat $\mathrm{mGlu}_{2} / \mathrm{HEK} / \mathrm{GIRK}$ and rat $\mathrm{mGlu}_{4} / \mathrm{HEK} / \mathrm{GIRK}$ cells were cultured in growth media as previously described (Niswender et al., 2008a), supplemented with nonessential amino acids. Rat $\mathrm{mGlu}_{4}$ was also subcloned into the pIREShyg3 vector, and the resulting plasmid was transfected into rat $\mathrm{mGlu}_{2} / \mathrm{HEK} /$ GIRK cells; cells were then selected with $200 \mu \mathrm{g} / \mathrm{ml}$ hygromycin B. Polyclonal cells were cultured in growth media supplemented with $100 \mu \mathrm{g} / \mathrm{ml}$ hygromycin B.

Western blot analysis. Cells were scraped into lysis buffer (50 mM Tris$\mathrm{HCl}, \mathrm{pH} 7.5,150 \mathrm{~mm} \mathrm{NaCl}, 0.5 \%$ Nonidet P40, and $0.5 \%$ deoxycholate) containing protease inhibitor mixture (Roche) and incubated on ice for 20-30 min. The supernatant was separated from cell debris by centrifugation at $16,000 \times \mathrm{g}$ for $10 \mathrm{~min}$ at $4^{\circ} \mathrm{C}$. Protein concentrations in cell lysates were quantified by Bio-Rad Protein Assay (Bio-Rad) or Bradford protein assay (Bio-Rad), and aliquots of lysate were heated in SDS sample buffer (containing $10 \%$ SDS and $9.3 \%$ DTT) at $65^{\circ} \mathrm{C}$ for $5 \mathrm{~min}$. Samples were loaded on SDS-PAGE and transferred to nitrocellulose membranes (Bio-Rad). After transfer, membranes were blocked in TBST $(25 \mathrm{~mm}$ Tris, $150 \mathrm{~mm} \mathrm{NaCl}$, and $0.05 \%$ Tween 20 ) containing 5\% nonfat milk at room temperature for $1 \mathrm{~h}$. mGlu $\mathrm{m}_{2}$ antibodies (Advanced Targeting Systems, catalog \#AB-N32) and $\mathrm{mGlu}_{4 \mathrm{a}}$ antibodies (Millipore, catalog \#06-765) were diluted in blocking solution and incubated with the membranes at $4^{\circ} \mathrm{C}$ overnight. Membranes were then washed with TBST and incubated with HRP-conjugated goat anti-mouse IgG secondary antibody (Santa Cruz Biotechnology, catalog \#sc-2060, 1:7500 diluted in blocking buffer, Jackson ImmunoResearch Laboratories, catalog \#115-035-166, $1: 10,000$ diluted in blocking buffer) for $\mathrm{mGlu}_{2}$ or HRP-conjugated goat anti-rabbit IgG secondary antibody (Santa Cruz Biotechnology, catalog \#sc-2004, 1:7500 diluted in blocking buffer or Jackson ImmunoResearch Laboratories, catalog \#111-035-144, 1:10,000 diluted in blocking buffer) for $\mathrm{mGlu}_{4}$ at room temperature for $1 \mathrm{~h}$. Membranes were washed again with TBST, and an enhanced chemiluminescent assay (Thermo Scientific, catalog \#32106 or 34075) was performed to detect immunoreactive proteins.

Coimmunoprecipitation. In cell line experiments, $\mathrm{mGlu}_{2} / \mathrm{HEK} / \mathrm{GIRK}$, $\mathrm{mGlu}_{4} / \mathrm{HEK} / \mathrm{GIRK}$, and $\mathrm{mGlu}_{2 / 4} / \mathrm{HEK} / \mathrm{GIRK}$ cells were lysed with immunoprecipitation lysis buffer (50 mM Tris- $\mathrm{HCl}, \mathrm{pH}$ 7.5, $150 \mathrm{~mm} \mathrm{NaCl}$, 2 mm EDTA, 1\% Nonidet P40 with Complete Mini protease inhibitor mixture, Roche, catalog \#04693159001) for immunoprecipitation experiments using the $\mathrm{mGlu}_{4}$ antibody; buffer was supplemented with $0.5 \%$ sodium deoxycholate for experiments using the $\mathrm{mGlu}_{2}$ antibody. Cell lysates were passed through G27 needles and incubated on ice for $30 \mathrm{~min}$. The supernatant was centrifuged and precleared with protein $\mathrm{A} / \mathrm{G}$ beads (Santa Cruz Biotechnology, sc-2003) at $4^{\circ} \mathrm{C}$ for $2-3 \mathrm{~h}$. mGlu (Advanced $^{2}$ Targeting Systems, catalog \#AB-N32) or $\mathrm{mGlu}_{4}$ (Millipore, catalog \#06765 ) antibodies were bound to protein $\mathrm{A} / \mathrm{G}$ beads by rotating at $4^{\circ} \mathrm{C}$ for $2-3 \mathrm{~h}$. Precleared cell lysates were then added to antibody-bound protein A/G beads or to beads without antibody as a negative control. After overnight rotation at $4^{\circ} \mathrm{C}$, the beads were washed 3 times with washing buffer (immunoprecipitation lysis buffer without EDTA or protease inhibitors) and pelleted by low-speed centrifugation. SDS sample buffer was added to elute bound proteins. Samples were heated at $65^{\circ} \mathrm{C}$ for 5 min and subjected to SDS-PAGE and Western blot analysis.
For coimmunoprecipitation assays in rat or mouse brain samples, Sprague Dawley rats of mixed gender (Charles River) and ICR (CD-1) male mice (Harlan) 22-30 d old were anesthetized under isoflurane anesthesia, decapitated, and brains were rapidly removed and cut into $0.5-1$ $\mathrm{mm}$ coronal slices using a brain matrix or a vibratome (Leica). Slices were transferred to a chilled metal surface, and dorsal striatum and medial prefrontal cortex (prelimbic and infralimbic regions) were dissected using a scalpel blade and immediately frozen on dry ice. Samples were homogenized in buffer containing the following (in $\mathrm{mm}$ ): 50 Tris $\mathrm{HCl}$, pH 7.4, $50 \mathrm{NaCl}, 10$ EGTA, 5 EDTA, $2 \mathrm{NaF}, 1 \mathrm{Na}_{3} \mathrm{VO}_{4}, 1$ PMSF supplemented with $1 \times$ Complete Mini protease inhibitor mixture, phosphatase inhibitor cocktails 2 and 3 (Sigma-Aldrich). Homogenized samples were centrifuged at $16,100 \times \mathrm{g}$ for $15 \mathrm{~min}$ at $4^{\circ} \mathrm{C}$, and pelleted membranes were stored at $-80^{\circ} \mathrm{C}$. Membrane pellets were resuspended in immunoprecipitation lysis buffer (same as immunoprecipitation lysis buffer for immunoprecipitation $\mathrm{mGlu}_{4}$ in cell lines, supplemented with $1 \mathrm{~mm}$ PMSF) and rocked/rotated/incubated at $4^{\circ} \mathrm{C}$ for $1 \mathrm{~h}$. Supernatant was prepared by centrifugation at $16,100 \times \mathrm{g}$ for $15 \mathrm{~min}$ and precleared by protein $\mathrm{A} / \mathrm{G}$ beads at $4^{\circ} \mathrm{C}$ for $2-3 \mathrm{~h}$. $\mathrm{mGlu}_{4}$ antibodies or normal rabbit IgG (Millipore, catalog \#12-370) were bound to protein A/G beads by rotating at $4^{\circ} \mathrm{C}$ for $2-3 \mathrm{~h}$. Precleared cell lysates were then added to $\mathrm{mGlu}_{4}$ antibody bound protein $\mathrm{A} / \mathrm{G}$ beads or rabbit IgG-coupled beads as a negative control. After overnight rotation at $4^{\circ} \mathrm{C}$, the beads were washed and samples were eluted and analyzed as described above.

Thallium flux assays. Thallium flux assays were performed according to methods described previously (Niswender et al., 2008b) with minor modifications. For dye loading, media was exchanged with assay buffer (HBSS, containing 20 mM HEPES, pH 7.4) using an ELX405 microplate washer (BioTek), leaving $20 \mu \mathrm{l} /$ well, followed by addition of $20 \mu \mathrm{l} /$ well $2 \times$ FluoZin-2 AM (330 nM final) indicator dye, (Invitrogen, prepared as a DMSO stock and mixed in a 1:1 ratio with pluronic acid F-127) in assay buffer. After a $1 \mathrm{~h}$ incubation at room temperature, dye was exchanged with assay buffer, leaving $20 \mu \mathrm{l} /$ well. Thallium flux was measured at room temperature using a Functional Drug Screening System 7000 (Hamamatsu). Baseline readings were taken ( 2 images at $1 \mathrm{~Hz}$; excitation, $470 \pm 20 \mathrm{~nm}$; emission, $540 \pm 30 \mathrm{~nm}$ ), and test compounds $(2 \times)$ were added in a $20 \mu \mathrm{l}$ volume and incubated for $140 \mathrm{~s}$ before the addition of $10 \mu \mathrm{l}$ of thallium buffer with or without agonist $(5 \times)$. Data were collected for an additional $2.5 \mathrm{~min}$ and analyzed using Excel (Microsoft) as previously described (Niswender et al., 2008b), and the concentration-response curves were fitted to a four-parameter logistic equation to determine potency estimates using GraphPad Prism as follows:

$$
y=\text { bottom }+\frac{\text { top }- \text { bottom }}{1+10^{(\text {LogEC } 50-A) \text { Hillslope }}}
$$

where $A$ is the molar concentration of the compound, bottom and top denote the lower and upper plateaus of the concentration-response curve, HillSlope is the Hill coefficient that describes the steepness of the curve; and $\mathrm{EC}_{50}$ is the molar concentration of compound required to generate a response halfway between the top and bottom.

Operational modeling of allosterism. Shifts of agonist concentrationresponse curves by allosteric modulators were globally fitted to an operational model of allosterism (Leach et al., 2007):

$$
\begin{aligned}
y & =\text { basal } \\
& +\frac{\left(E_{m}-\text { basal }\right)\left(\tau_{A}[A]\left(K_{B}+\alpha \beta[B]\right)+\tau_{B}[B] K_{A}\right)^{n}}{\left(\tau_{A}[A]\left(K_{B}+\alpha \beta[B]\right)+\tau_{B}[B] K_{A}\right)^{n}+\left([A] K_{B}+K_{A} K_{B}+K_{A}[B]+\alpha[A][B]\right)^{n}}
\end{aligned}
$$

where $A$ is the molar concentration of the orthosteric agonist, $B$ is the molar concentration of the allosteric modulator, $K_{A}$ is the equilibrium dissociation constant of the orthosteric agonist, and $K_{B}$ is the equilibrium dissociation constant of allosteric modulator. Affinity modulation is governed by the cooperativity factor $\alpha$, and efficacy modulation is governed by $\beta$. The parameters $\tau_{\mathrm{A}}$ and $\tau_{\mathrm{B}}$ relate to the ability of orthosteric agonist and allosteric ligands, respectively, to directly activate the receptor. Basal, $E_{\mathrm{m}}$, and $n$ represent the basal system response, maximal possible system response, and the transducer function that links occupancy to response. 
Alternatively, a simplified version of this model was applied to estimate a composite cooperativity parameter $(\alpha \beta)$ for PAMs (Leach et al., 2007):

$y=$ basal

$$
+\frac{\left(E_{m}-\text { basal }\right)\left(\tau_{A}[A]\left(K_{B}+\alpha \beta[B]\right)+\tau_{B}[B] K_{A}\right)^{n}}{\left(\tau_{A}[A]\left(K_{B}+\alpha \beta[B]\right)+\tau_{B}[B] K_{A}\right)^{n}+\left(K_{A}\left(K_{B}+[B]\right)\right)^{n}}
$$

where all parameters are as described above.

For the simulation of $\mathrm{mGlu}_{4}$ PAM effects, the $\log K_{A}$ of L-AP4 for $\mathrm{mGlu}_{4}$ was set to -6.759 according to literature values (Monastyrskaia et al., 1999) and was assumed to be unaltered at $\mathrm{mGlu}_{2 / 4}$ hetero-complexes. For PHCCC and 4 PAM-2, $\log \tau_{\mathrm{B}}$ was set to -100 because of the lack of allosteric agonist activity but was allowed to float for compounds exhibiting allosteric agonism (VU0155041, Lu-AF29134). For the analysis of MNI-137, the $\log K_{A}$ of DCG-IV for $\mathrm{mGlu}_{2}$ was set to -6.959 according to literature values (Schweitzer et al., 2000) and was assumed to be unaltered at $\mathrm{mGlu}_{2 / 4}$ hetero-complexes; $\log \tau_{\mathrm{B}}$ was set to -100 .

Transient transfections. Two days before the assay, combinations of pIRES-hyg3-rat $\mathrm{mGlu}_{2}$, pIRES-hyg3-rat $\mathrm{mGlu}_{4}$, and pIRES-hyg3-rat $\mathrm{mGlu}_{7}$ were cotransfected with ratios of $0 \mu \mathrm{g}: 1 \mu \mathrm{g}, 0.1 \mu \mathrm{g}: 1 \mu \mathrm{g}, 0.2 \mu \mathrm{g}: 1$ $\mu \mathrm{g}, 0.5 \mu \mathrm{g}: 1 \mu \mathrm{g}$ or $1 \mu \mathrm{g}: 1 \mu \mathrm{g}$ of DNA into HEK/GIRK cells using Fugene 6 (Promega) according to the manufacturer's protocol. After $24 \mathrm{~h}$, cells were trypsinized and plated in 384-well poly D-lysine-coated plates using assay media. Plates were then tested the next day using the thallium flux assay as described above.

Whole-cell patch-clamp recordings. Whole-cell patch-clamp recordings were performed using coronal slices prepared from 15- to 19-day-old Sprague Dawley rats of mixed gender (Charles River). Animals were anesthetized with isoflurane, and brains were removed and submerged into ice-cold cutting solution (in mM 220 sucrose, $2.5 \mathrm{KCl}, 1.25 \mathrm{NaH}_{2} \mathrm{PO}_{4}$, $26.2 \mathrm{NaHCO}_{3}, 10 \mathrm{D}$-glucose, $0.5 \mathrm{CaCl}_{2}, 8 \mathrm{MgCl}_{2}$ ). Coronal slices containing the striatum were cut at $300 \mu \mathrm{m}$ using a vibratome (Leica VT 1200S) or a compresstome (Precisionary Instruments). Slices were transferred to a holding chamber containing ACSF (in mM: $126 \mathrm{NaCl}, 2.5 \mathrm{KCl}, 1.2$ $\mathrm{NaH}_{2} \mathrm{PO}_{4}, 25 \mathrm{NaHCO}_{3}, 11$ D-glucose, $2.4 \mathrm{CaCl}_{2}, 1.2 \mathrm{MgCl}_{2}$ ) supplemented with $5 \mu \mathrm{M}$ glutathione, for slice viability, for $25 \mathrm{~min}$ at $32^{\circ} \mathrm{C}$. All buffers were continuously bubbled with $95 \% \mathrm{O}_{2} / 5 \% \mathrm{CO}_{2}$. Subsequently, slices were maintained at room temperature for at least $30 \mathrm{~min}$ in ACSF, then transferred to a submersion recording chamber where they were perfused with room temperature ACSF at a rate of $2 \mathrm{ml} / \mathrm{min}$. Neurons were visualized with a $40 \times$ water-immersion lens with Hoffman modulation contrast optics coupled with an Olympus BX50WI upright microscope (Olympus). Borosilicate glass patch electrodes were pulled using a Flaming/Brown micropipette puller (Sutter Instruments) and had a resistance of 4-6 $\mathrm{M} \Omega$ when filled with an intracellular solution containing (in mM: 123 potassium gluconate, $7 \mathrm{KCl}, 0.025 \mathrm{CaCl}_{2}, 1 \mathrm{MgCl}_{2}, 10$ HEPES, 0.1 EGTA, 2 magnesium-ATP, 0.2 sodium-GTP, $\mathrm{pH}$ adjusted to 7.3 with $1 \mathrm{~N} \mathrm{KOH} ; 295 \mathrm{mOsm}$ ).

Whole-cell recordings were made from medium spiny neurons, which were visually identified and then confirmed by determining the currentvoltage relationship of positive or negative current injections; a MultiClamp 700B amplifier (Molecular Devices) was used for current-clamp recordings. Data were digitized with a DigiData 1331 system (Molecular Devices) and acquired using pClamp10.2 (Molecular Devices). EPSPs were evoked in medium spiny neurons by placing a bipolar electrode in the white matter between the cortex and striatum. After formation of a whole-cell configuration, membrane potential was recorded and current was injected to maintain resting membrane potential at $-75 \mathrm{mV}$, and changes in membrane potential were recorded. Compounds were diluted in ACSF and bath applied as noted. Data were analyzed using Clampfit 10.2 (Molecular Devices).

Drugs. Glutamate, DCG-IV, CBiPES, and LY487379 were purchased from Tocris Biosciences. L-AP4, LY379268, and PHCCC were purchased from Abcam Biochemicals. cis-2-[[(3,5-Dichlorophenyl)amino]carbonyl] cyclohexanecarboxylic acid (VU0155041), N-(4-(N-(2-chlorophenyl) sulfamoyl)phenyl)picolinamide (4PAM-2), (1S,2R)-N1-(3,4-dichlorophenyl) cyclohexane-1,2-dicarboxamide (Lu AF21934), and biphenylindanone A (BINA) were synthesized in-house. Synthesis of VU0155041, BINA, and MNI-137 was performed according to methods previously described (Galici et al., 2006; Hemstapat et al., 2007; Niswender et al., 2008b).

Synthesis of 4PAM-2 and Lu AF21934 was performed according to methods described below: General. All NMR spectra were recorded on a $400 \mathrm{MHz}$ AMX Bruker NMR spectrometer. ${ }^{1} \mathrm{H}$ chemical shifts are reported in $\delta$ values in ppm downfield with the deuterated solvent as the internal standard. Data are reported as follows: chemical shift, multiplicity $(\mathrm{s}=$ singlet, $\mathrm{d}=$ doublet, $\mathrm{t}=$ triplet, $\mathrm{q}=$ quartet, $\mathrm{br}=$ broad, $\mathrm{m}=$ multiplet), integration, coupling constant $(\mathrm{Hz})$. Low resolution mass spectra were obtained on an Agilent 1200 series 6130 mass spectrometer with electrospray ionization. High-resolution mass spectra were recorded on a Waters Q-TOF API-US plus Acquity system with electrospray ionization. Analytical thin-layer chromatography was performed on EM Reagent $0.25 \mathrm{~mm}$ silica gel $60-\mathrm{F}$ plates. Analytical HPLC was performed on an Agilent 1200 series with UV detection at 214 and $254 \mathrm{~nm}$ along with ELSD detection. LC/MS: Restek-C18, 3.2×30 mm, $2 \mathrm{~min}$ gradient, $10 \%\left[0.05 \% \mathrm{TFA} / \mathrm{CH}_{3} \mathrm{CN}\right]: 90 \%\left[0.05 \% \mathrm{TFA} / \mathrm{H}_{2} \mathrm{O}\right]$ to $100 \%$ $\left[0.1 \% \mathrm{TFA} / \mathrm{CH}_{3} \mathrm{CN}\right]$ or PhenomenexC18, $2.1 \times 30 \mathrm{~mm}, 1$ min gradient, $7 \%\left[0.1 \% \mathrm{TFA} / \mathrm{CH}_{3} \mathrm{CN}\right]: 93 \%\left[0.1 \% \mathrm{TFA} / \mathrm{H}_{2} \mathrm{O}\right]$ to $95 \%[0.1 \% \mathrm{TFA} /$ $\left.\mathrm{CH}_{3} \mathrm{CN}\right]$. Preparative purification was performed on a custom HP1100 purification system with collection triggered by mass detection. Solvents for extraction, washing and chromatography were HPLC grade. All reagents were purchased from Aldrich Chemical Co. and were used without purification.

4PAM-2:

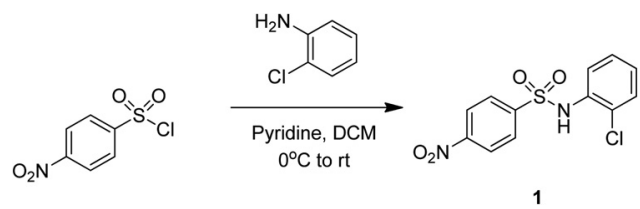

To a solution of 2-chloroaniline $(0.95 \mathrm{ml}, 9.02 \mathrm{mmol}, 1.0 \mathrm{eq})$ in pyridine $(5 \mathrm{ml})$ and $\mathrm{DCM}(5 \mathrm{ml})$ at $0^{\circ} \mathrm{C}$ was added 4-nitrobenzenesulfonylchloride ( $2.0 \mathrm{~g}, 9.02 \mathrm{mmol}, 1.0 \mathrm{eq})$. After $15 \mathrm{~min}$, the cold bath was removed. After an additional $24 \mathrm{~h}$ at room temperature, the rxn was added to $1 \mathrm{~N} \mathrm{HCl}(\mathrm{aq})(50 \mathrm{ml})$ and DCM $(50 \mathrm{ml})$. The organic layer was separated, washed with $1 \mathrm{~N} \mathrm{HCl}(\mathrm{aq})(20 \mathrm{ml}), \mathrm{H}_{2} \mathrm{O}(2 \times 20 \mathrm{ml})$, brine $(20 \mathrm{ml})$, and dried $\left(\mathrm{MgSO}_{4}\right)$. The mixture was filtered and concentrated to afford 1 (2.73 g, 97\%). The residue was carried through without further purification.

$\mathrm{R}_{\mathrm{f}} 0.85$ (50\% EtOAc/hexanes);

LCMS: $\mathrm{R}_{\mathrm{t}}=1.403 \mathrm{~min}, \mathrm{M}+\mathrm{H}=313.0 ;>98 \%$ at 215 and $254 \mathrm{~nm}$

${ }^{1} \mathrm{HNMR}\left(400 \mathrm{MHz}, \mathrm{CDCl}_{3}\right): \delta 8.27(\mathrm{~d}, \mathrm{~J}=9.0 \mathrm{~Hz}, 2 \mathrm{H}), 7.92(\mathrm{~d}, \mathrm{~J}=9.0$ $\mathrm{Hz}, 2 \mathrm{H}), 7.70(\mathrm{dd}, \mathrm{J}=8.1,1.4 \mathrm{~Hz}, 1 \mathrm{H}), 7.32-7.26(\mathrm{~m}, 2 \mathrm{H}), 7.13(\mathrm{ddd}, \mathrm{J}=$ $8.8,8.8,1.5 \mathrm{~Hz}, 1 \mathrm{H}), 7.01$ (br s, $1 \mathrm{H}$ ):

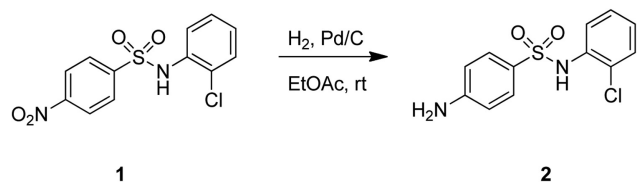

To a solution of $1(2.73 \mathrm{~g}, 8.73 \mathrm{mmol}, 1.0 \mathrm{eq})$ in EtOAc $(40 \mathrm{ml})$ was added $5 \% \mathrm{Pd} / \mathrm{C}(\sim 150 \mathrm{mg})$. The rxn atmosphere was evacuated and purged with $\mathrm{H}_{2}$ balloon ( $\left.1 \mathrm{~atm}\right)$. The rxn was followed by TLC. After $4 \mathrm{~h}$, the rxn mixture was filtered through Celite and concentrated to provide a white solid (2.45 g, 99\%).

$\mathrm{R}_{\mathrm{f}} 0.50$ (50\% EtOAc/hexanes);

${ }^{1} \mathrm{H} \mathrm{NMR}\left(400 \mathrm{MHz}, \mathrm{CDCl}_{3}\right): \delta 7.64(\mathrm{dd}, \mathrm{J}=8.2,1.4 \mathrm{~Hz}, 1 \mathrm{H}), 7.54(\mathrm{~d}$, $\mathrm{J}=8.7 \mathrm{~Hz}, 2 \mathrm{H}), 7.24-7.19(\mathrm{~m}, 2 \mathrm{H}), 7.01(\mathrm{ddd}, \mathrm{J}=7.8,7.8,1.5 \mathrm{~Hz}, 1 \mathrm{H})$, $6.91($ br s, $1 \mathrm{H}), 6.58(\mathrm{~d}, \mathrm{~J}=8.8 \mathrm{~Hz}, 2 \mathrm{H}), 4.11(\mathrm{br} \mathrm{s}, 2 \mathrm{H})$ :

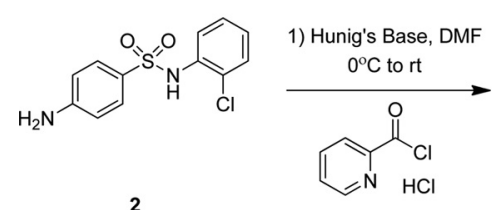

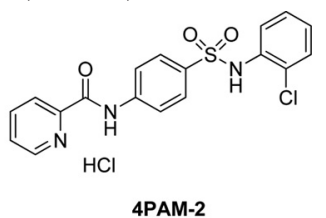

4PAM-2
2) $4 \mathrm{M} \mathrm{HCl}$ in dioxane 
To a solution of $2(2.45 \mathrm{~g}, 8.66 \mathrm{mmol}, 1.0 \mathrm{eq})$ in DMF $(16 \mathrm{ml})$ and Hunig's Base $(3.64 \mathrm{ml}, 25.98 \mathrm{mmol}, 3.0 \mathrm{eq})$ at $0^{\circ} \mathrm{C}$ was added picolinoyl chloride hydrochloride ( $1.70 \mathrm{~g}, 9.53 \mathrm{mmol}, 1.1 \mathrm{eq})$. After $15 \mathrm{~min}$, the ice bath was removed. After an additional $24 \mathrm{~h}$ at room temperature, the rxn was added to EtOAc: $\mathrm{H}_{2} \mathrm{O}(1: 1,100 \mathrm{ml})$. The organic layer was separated and washed with $\mathrm{H}_{2} \mathrm{O}(2 \times 50 \mathrm{ml})$, brine $(50 \mathrm{ml})$, dried $\left(\mathrm{MgSO}_{4}\right)$, and concentrated. The residue was purified by reverse phase liquid column chromatography ( $40-80 \%$ acetonitrile: $\mathrm{H}_{2} \mathrm{O}$ with $0.1 \%$ trifluoroacetic acid). The collected fractions were added to EtOAc: $\mathrm{NaHCO}_{3}(\mathrm{aq})(1: 1$, $100 \mathrm{ml})$. The organic layer was separated and washed with $\mathrm{H}_{2} \mathrm{O}(50 \mathrm{ml})$, brine $(50 \mathrm{ml})$, dried $\left(\mathrm{MgSO}_{4}\right)$, filtered, and concentrated to afford a white solid. The white solid was dissolved in DCM $(25 \mathrm{ml})$ and $4 \mathrm{~N} \mathrm{HCl}$ in dioxane ( $5 \mathrm{ml}$ ) was added. After $5 \mathrm{~min}$, the solvent was removed to yield $4 \mathrm{PAM}-2$ as an $\mathrm{HCl}$ salt ( $1.06 \mathrm{~g}, 32 \%$ yield).

LCMS: $\mathrm{R}_{\mathrm{t}}=1.455 \mathrm{~min}, \mathrm{M}+\mathrm{H}=387.8 ;>98 \%$ at 215 and $254 \mathrm{~nm}$

${ }^{1} \mathrm{H}$ NMR (400 MHz, $d$-DMSO): $\delta 11.01(\mathrm{~s}, 1 \mathrm{H}), 9.92(\mathrm{~s}, 1 \mathrm{H}), 8.77$ (d, $\mathrm{J}=4.2 \mathrm{~Hz}, 1 \mathrm{H}), 8.18(\mathrm{~d}, \mathrm{~J}=7.6 \mathrm{~Hz}, 1 \mathrm{H}), 8.10(\mathrm{~d}, \mathrm{~J}=8.7 \mathrm{~Hz}, 2 \mathrm{H})$, $8.09-8.08(\mathrm{~m}, 1 \mathrm{H}), 7.73-7.71(\mathrm{~m}, 1 \mathrm{H}), 7.71(\mathrm{~d}, \mathrm{~J}=8.8 \mathrm{~Hz}, 2 \mathrm{H}), 7.41(\mathrm{dd}$, $\mathrm{J}=7.8,1.2 \mathrm{~Hz}, 1 \mathrm{H}), 7.32-7.26(\mathrm{~m}, 2 \mathrm{H}), 7.23-7.19(\mathrm{~m}, 1 \mathrm{H})$;

HRMS, calculated for $\mathrm{C}_{18} \mathrm{H}_{14} \mathrm{~N}_{3} \mathrm{O}_{3} \mathrm{NaSCl}\left(\mathrm{M}+\mathrm{Na}^{+}\right), 410.0342$; found 410.0339 .

Lu AF21934:<smiles>O=C1OC(=O)C2CCCCC12</smiles><smiles>Nc1ccc(Cl)c(Cl)c1</smiles>

reflux

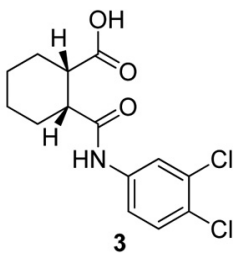

3
Into a $50 \mathrm{ml}$ round bottom flask, containing a magnetic stir bar, was weighed $1.3751 \mathrm{mmol}(212 \mathrm{mg})$ of cyclohexyldicarboxylic anhydride (predominantly cis-) followed by $6 \mathrm{ml}$ chloroform. To this solution was added $0.9167 \mathrm{mmol}$ (148.5 mg) of 3,4-dichloroaniline. After being fitted with a reflux column, the reaction mixture was heated in an oil bath to reflux at $70^{\circ} \mathrm{C}$ for $2 \mathrm{~h}$, with magnetic stirring. Over this time, a white solid crashed out of the reaction mixture. After cooling the reaction to ambient temperature, the solid was isolated via vacuum filtration and washed with cold chloroform to obtain $434.8 \mathrm{mg}$ of the desired product, $3(78.4 \%$ yield) as a crystalline white powder.

LCMS: $\mathrm{R}_{\mathrm{t}}=0.741 \mathrm{~min}, \mathrm{M}+\mathrm{H}=315.7 ;>98 \%$ at 215 and $254 \mathrm{~nm}$;

HRMS calculated for $\mathrm{C}_{14} \mathrm{H}_{15} \mathrm{Cl}_{2} \mathrm{NO}_{3}[\mathrm{M}+\mathrm{H}]$ : 315.0667 found 315.0668;

${ }^{1} \mathrm{H}$ NMR (400 MHz, methyl sulfoxide- $d_{6}$ calibrated to 2.54) $\delta 10.02$ (s, $1 \mathrm{H}), 7.99(\mathrm{~d}, \mathrm{~J}=2.39 \mathrm{~Hz}, 1 \mathrm{H}), 7.53(\mathrm{~d}, \mathrm{~J}=8.79 \mathrm{~Hz}, 1 \mathrm{H}), 7.46(\mathrm{dd}, \mathrm{J}=$ 8.87, $2.43 \mathrm{~Hz}, 1 \mathrm{H}), 2.92(\mathrm{q}, \mathrm{J}=4.78 \mathrm{~Hz}, 1 \mathrm{H}), 2.64-2.60(\mathrm{~m}, 1 \mathrm{H}), 2.12-$ $2.03(\mathrm{~m}, 1 \mathrm{H}), 1.99-1.94(\mathrm{~m}, 1 \mathrm{H}), 1.76-1.61(\mathrm{~m}, 3 \mathrm{H}), 1.41-1.29(\mathrm{~m}, 3 \mathrm{H})$ :<smiles>O=C(O)C1CCCCC1C(=O)Nc1ccc(Cl)c(Cl)c1</smiles>

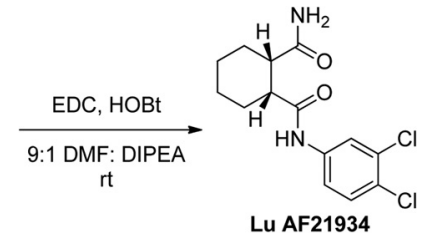

To a $4 \mathrm{ml}$ vial were weighed $0.3115 \mathrm{mmol}(98.5 \mathrm{mg})$ compound 3, $0.9345 \mathrm{mmol}(98.5 \mathrm{mg})$ ammonium chloride, $0.3738 \mathrm{mmol}(71.5 \mathrm{mg})$ 1-ethyl-3-(3-dimethylaminopropyl)carbodiimide, and $0.3115 \mathrm{mmol}$ (42.1 mg), hydroxybenzotriazole, followed by $3 \mathrm{ml}$ of 9:1 dimethylformamide:diisopropylethylamine. The reaction vial was rotated at room temperature overnight. The reaction was diluted with ethyl acetate $(\sim 5 \mathrm{ml})$ and washed with brine. The organic phase was separated and dried over sodium sulfate. Solvent was removed under reduced pressure, and the crude product was purified via flash column chromatography. Product-containing fractions were combined and the solvents removed under reduced pressure to obtain $31 \mathrm{mg}$ of the desired product, $\mathrm{Lu}$ AF21934 (31.5\% yield) as an off-white powder.

LCMS: $0.690 \mathrm{~min}, \mathrm{M}+\mathrm{H}=314.7 ;>98 \%$ at 215 and $254 \mathrm{~nm}$;

HRMS calculated for $\mathrm{C}_{14} \mathrm{H}_{16} \mathrm{Cl}_{2} \mathrm{~N}_{2} \mathrm{O}_{2}[\mathrm{M}+\mathrm{H}]$ : 316.0507 found 316.0507;

${ }^{1} \mathrm{H}$ NMR (400 MHz, methyl sulfoxide- $d_{6}$ calibrated to 2.54): $\delta 9.92$ (s, $1 \mathrm{H}), 8.01(\mathrm{~d}, \mathrm{~J}=2.27 \mathrm{~Hz}, 1 \mathrm{H}), 7.51(\mathrm{~d}, \mathrm{~J}=8.91 \mathrm{~Hz}, 1 \mathrm{H}), 7.44(\mathrm{dd}, \mathrm{J}=$
8.88, 2.42, 1H), $7.06(\mathrm{~s}, 1 \mathrm{H}), 6.72(\mathrm{~s}, 1 \mathrm{H}), 2.80(\mathrm{q}, \mathrm{J}=4.83 \mathrm{~Hz}, 1 \mathrm{H})$, $2.50-2.46(\mathrm{~m}, 1 \mathrm{H}), 2.15-1.98(\mathrm{~m}, 1 \mathrm{H}), 1.70-1.48(\mathrm{~m}, 1 \mathrm{H}), 1.39-1.23$ $(\mathrm{m}, 1 \mathrm{H})$.

Animal studies. Animals were maintained in accordance with the guidelines of the American Association for the Accreditation of Laboratory Animal Care under a $12 \mathrm{~h}$ light/dark cycle (lights on 06:00 to 18:00) with free access to food and water. All experiments were approved by Vanderbilt University's Institutional Animal Care and Use Committee and conformed to guidelines established by the National Research Council Guide for the Care and Use of Laboratory Animals. All efforts were made to minimize animal suffering and the number of animals used.

Statistical analysis. All data shown represent mean \pm SEM value for at least three replicates. Statistical significance between groups was determined using unpaired Student's $t$ tests or ANOVA (with Dunnett's or Bonferroni's post test) as specified in each figure legend.

\section{Results \\ PHCCC fails to potentiate L-AP4-induced decreases in evoked EPSP (eEPSP) amplitude at corticostriatal synapses}

PHCCC is the first described $\mathrm{mGlu}_{4}$-PAM (Maj et al., 2003; Marino et al., 2003) and has been used to probe the activity of $\mathrm{mGlu}_{4}$ at various synapses in the basal ganglia and other brain regions (Marino et al., 2003; Valenti et al., 2005; Jones et al., 2008). The efficacy of PHCCC at striatopallidal and STN-SNc synapses is consistent with its symptomatic and disease-modifying effects in PD animal models (Marino et al., 2003; Battaglia et al., 2006). In addition to striatopallidal and STN-SNc synapses, immunohistochemistry studies revealed that $\mathrm{mGlu}_{4}$ is expressed at corticostriatal synapses, which represent the primary input to the basal ganglia from the motor cortex (Corti et al., 2002). Consistent with expression studies, Bennouar et al. (2013) recently reported that the $\mathrm{mGlu}_{4}$ PAM Lu AF21934 reduces corticostriatal transmission. To further understand the role of $\mathrm{mGlu}_{4}$ in regulation of basal ganglia function, we evaluated the ability of PHCCC to reduce corticostriatal transmission. In agreement with previous results (Pisani et al., 1997), $100 \mu \mathrm{M}$ L-AP4, a Group III selective mGlu receptor agonist, reduced eEPSPs measured in striatal medium spiny neurons after stimulation in the corpus callosum $(42.8 \pm 5.8 \%$ of baseline; Fig. $1 A)$. To determine whether PHCCC could potentiate the response to L-AP4, a concentration of L-AP4 that resulted in a small reduction in the eEPSP amplitude was identified. Five hundred nanomolars L-AP4 resulted in reduction in the eEPSP amplitude that was at the threshold for detection (90.5 $\pm 6.2 \%$ of baseline; Fig. 1B). Surprisingly, PHCCC did not potentiate the response to L-AP4 at this synapse; $30 \mu \mathrm{M}$ PHCCC, followed by the coaddition of $30 \mu \mathrm{M}$ PHCCC + $500 \mathrm{~nm}$ L-AP4, resulted in no change in eEPSP amplitude (90.1 \pm $7.1 \%$ of baseline; Fig. 1C) relative to $500 \mathrm{~nm}$ L-AP4 alone.

\section{$\mathrm{mGlu}_{4}$ interacts with $\mathrm{mGlu}_{2}$ to form hetero-complexes in vitro}

The lack of effect of PHCCC was surprising and contrasts with the ability of this compound to potentiate $\mathrm{mGlu}_{4}$ activity at other synapses (Marino et al., 2003; Valenti et al., 2005; Jones et al., 2008). In addition, this finding does not align with the ability of the structurally distinct $\mathrm{mGlu}_{4}$-selective PAM Lu AF21934 to potentiate $\mathrm{mGlu}_{4}$ agonist effects at corticostriatal synapses (Bennouar et al., 2013). Interestingly, both the Group II mGlu agonist LY379268 (Picconi et al., 2002) and the mGlu 2 PAM cyPPTS (Johnson et al., 2005) inhibit excitatory transmission at corticostriatal synapses via a presynaptic mechanism of action, suggesting that $\mathrm{mGlu}_{2}$ receptors are also expressed on corticostriatal terminals. Recent studies, including time-resolved FRET and coexpression studies, have shown that $\mathrm{mGlu}_{2}$ and $\mathrm{mGlu}_{4}$ form 


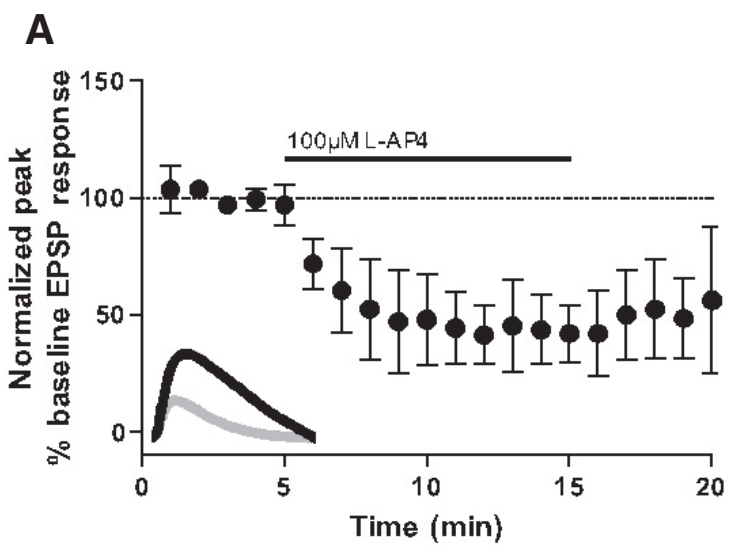

B

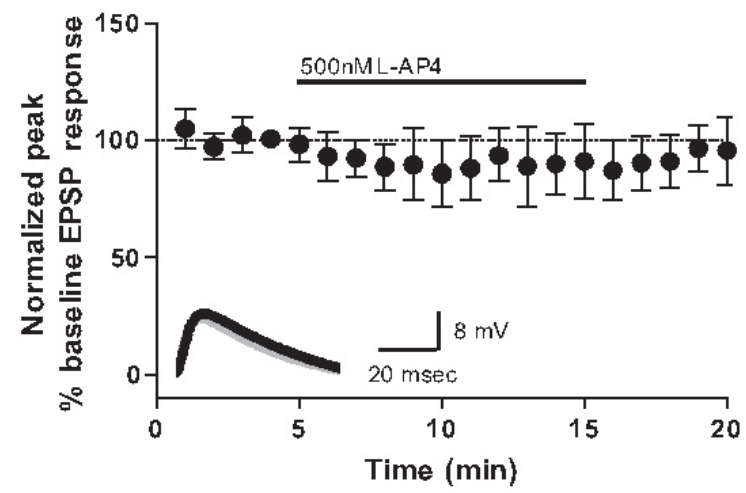

C

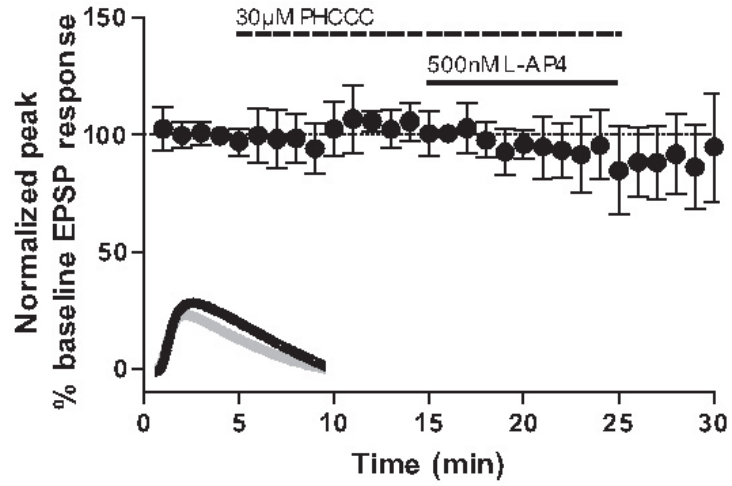

Figure 1. The mGlu 4 PAM PHCCC fails to potentiate L-AP4-induced decreases in eEPSPs at corticostriatal synapses. EPSPs were recorded in medium spiny neurons after stimulation of the white matter between the cortex and striatum with a bipolar electrode. All compounds were bath applied. Data are normalized to the average baseline EPSP amplitude. Insets, Sample traces from an individual, representative experiment. Black represents averaged traces from minute before L-AP4 application; gray represents averaged traces from last minute of L-AP4 application. Slices were treated with $100 \mu \mathrm{m} \mathrm{L}-\mathrm{AP4}(\boldsymbol{A}), 500 \mathrm{nmL}-\mathrm{AP} 4(\boldsymbol{B})$, or $30 \mu \mathrm{m}$ PHCCC followed by coapplication of $30 \mu \mathrm{M}$ PHCCC and $500 \mathrm{~nm} \mathrm{L-AP4}$ (C). Solid and dashed lines indicate time of compound additions. Values represent mean $\pm \operatorname{SEM}(n=5)$.

\section{Anti-mGlu}

A

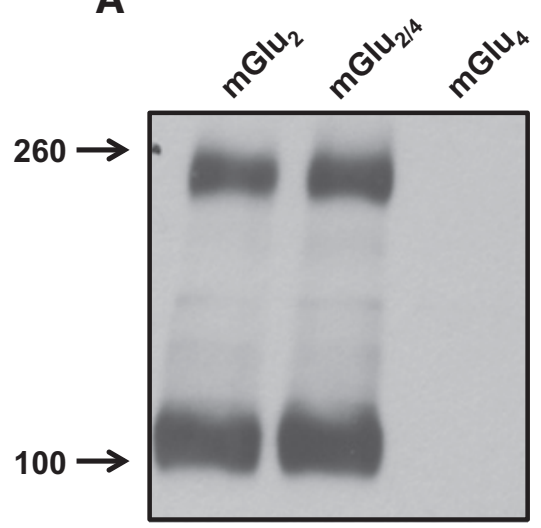

Anti-mGlu

B

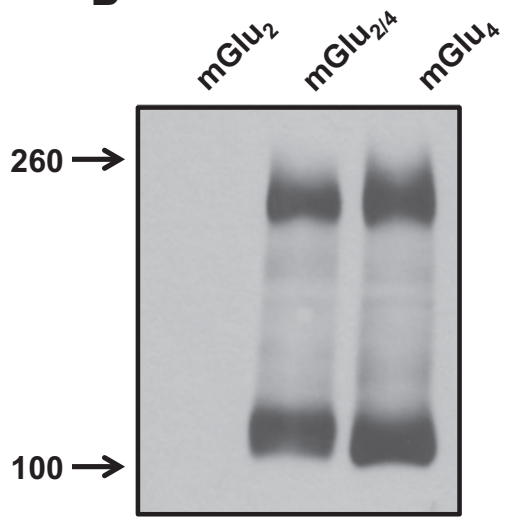

Figure 2. Similar expression levels of $\mathrm{mGlu}_{2}$ and $\mathrm{mGlu}_{4}$ in various cell lines. A total of $15 \mu \mathrm{g}$ of cell lysates from mGlu $\mathrm{mGlu}_{2 / 4}$ and $\mathrm{mGlu}_{4}$ cell lines was prepared as described. Receptor expression was analyzed by Western blots using anti-mGlu${ }_{2}(\boldsymbol{A}, 1: 1000$ dilution) and anti-mGlu 4 (B; 1:1000 dilution) antibodies.

heterodimers in vitro (Doumazane et al., 2011; Kammermeier, 2012), and we hypothesized that $\mathrm{mGlu}_{4}$-containing heteromers may be expressed on corticostriatal terminals and may not display the same response to PHCCC as that observed with $\mathrm{mGlu}_{4}$ homomers.

To test this hypothesis, an $\mathrm{mGlu}_{2 / 4}$ cell line was constructed by transfecting rat $\mathrm{mGlu}_{4}$ into rat $\mathrm{mGlu}_{2} / \mathrm{HEK}$ cells stably expressing GIRK channels, which allows assessment of receptor activity using a GIRK-mediated thallium flux assay (Niswender et al., 2008a). We established that the resulting $\mathrm{mGlu}_{2 / 4}$ cell line expressed similar amounts of both $\mathrm{mGlu}_{2}$ and $\mathrm{mGlu}_{4}$ protein compared with the parental cell lines expressing either receptor alone (Fig. 2 ). We then assessed the physical interaction between $\mathrm{mGlu}_{2}$ and $\mathrm{mGlu}_{4}$ using coimmunoprecipitation techniques. $\mathrm{mGlu}_{4}$ antibodies immunoprecipitated $\mathrm{mGlu}_{4}$ protein $(\sim 240 \mathrm{kDa}$ in dimeric form $)$ from the cell lysate of the $\mathrm{mGlu}_{4}$ and $\mathrm{mGlu}_{2 / 4}$ cell lines (Fig. 3B). A band of $\sim 100 \mathrm{kDa}$ was present in all of the immunoprecipitation samples and obscured specific identification of monomeric receptor protein; this band was present in immunoprecipitation samples without any cell lysate (data not shown), suggesting that it resulted from the antibody itself. In cells coexpressing $\mathrm{mGlu}_{2}$ and $\mathrm{mGlu}_{4}, \mathrm{mGlu}_{2}$ proteins were coprecipitated along with $\mathrm{mGlu}_{4}$ by $\mathrm{mGlu}_{4}$ antibody-coupled beads (Fig. 3D; 
$\sim 100 \mathrm{kDa}$ and $\sim 240 \mathrm{kDa}$ for monomeric and dimeric forms, respectively). In contrast, precipitation using the protein $\mathrm{A} / \mathrm{G}$ beads alone did not yield any specific bands. Additionally, precipitated $\mathrm{mGlu}_{2}$ was not detected in immunoprecipitations from the control $\mathrm{mGlu}_{2}$ or $\mathrm{mGlu}_{4}$ cell line. To eliminate the possibility that $\mathrm{mGlu}_{2}$ and $\mathrm{mGlu}_{4}$ proteins nonspecifically aggregated after the cells were lysed, we mixed the cell lysates from the $\mathrm{mGlu}_{2}-$ expressing cell line and the $\mathrm{mGlu}_{4}{ }^{-}$ expressing cell line and subjected the mixed sample to coimmunoprecipitation. The absence of precipitated $\mathrm{mGlu}_{2}$ in this mixed sample indicated that $\mathrm{mGlu}_{2 / 4}$ complexes were formed before, but not during or after, the lysis process. We further confirmed the physical interaction between $\mathrm{mGlu}_{2}$ and $\mathrm{mGlu}_{4}$ by swapping the bait and prey in additional coimmunoprecipitation experiments. When $\mathrm{mGlu}_{2}$ was used as the bait, $\mathrm{mGlu}_{4}$ proteins were also coimmunoprecipitated by $\mathrm{mGlu}_{2}$ antibodies only in the cell line that expressed both receptors (data not shown). These data support the hypothesis that $\mathrm{mGlu}_{2}$ specifically interacts in some manner with $\mathrm{mGlu}_{4}$ in vitro and can be coimmunoprecipitated with antibodies recognizing the native receptor proteins.

\section{$\mathrm{mGlu}_{2}$ and $\mathrm{mGlu}_{4}$ interact in rodent} brain tissue

After optimizing conditions for coimmunoprecipitation of $\mathrm{mGlu}_{2}$ and $\mathrm{mGlu}_{4}$ in cell lines, we tested the hypothesis that these receptors interact in brain tissue. Both $\mathrm{mGlu}_{2}$ and $\mathrm{mGlu}_{4}$ are expressed in dorsal striatum and medial prefrontal cortex of Sprague Dawley rats, as indicated by the immunoreactive monomeric and dimeric bands in tissue lysates (Fig. 3E-H, input). Whereas both $\mathrm{mGlu}_{4}$ antibodies and a rabbit IgG control generated antibody bands at $\sim 100 \mathrm{kDa}$, $\mathrm{mGlu}_{4}$ antibodies were able to precipitate dimeric $\mathrm{mGlu}_{4}$ from the dorsal striatum and medial prefrontal cortex $(\sim 240 \mathrm{kDa}$ in dimeric form; Fig. $3 E, F$ ). Conversely, immunoprecipitation using rabbit IgG did not yield any $\mathrm{mGlu}_{4}$-specific bands. In addition, when detected using $\mathrm{mGlu}_{2}$-specific antibodies, we found that $\mathrm{mGlu}_{2}$ proteins were coimmunoprecipitated by $\mathrm{mGlu}_{4}$ antibodies in both monomeric and dimeric forms $(\sim 100 \mathrm{kDa}$ and $240 \mathrm{kDa}$, respectively), but not by rabbit IgG (Fig. 3G,H). Similar results were also obtained in mouse dorsal striatum and medial prefrontal cortex (data not shown). Together, these data present the first evidence consistent with the existence of mGlu heteromers in vivo and suggest that $\mathrm{mGlu}_{2 / 4}$ heteromers may participate in the regulation of CNS function.

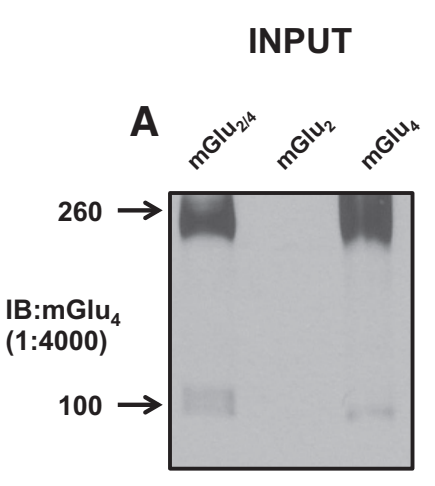

\section{HEK cells}
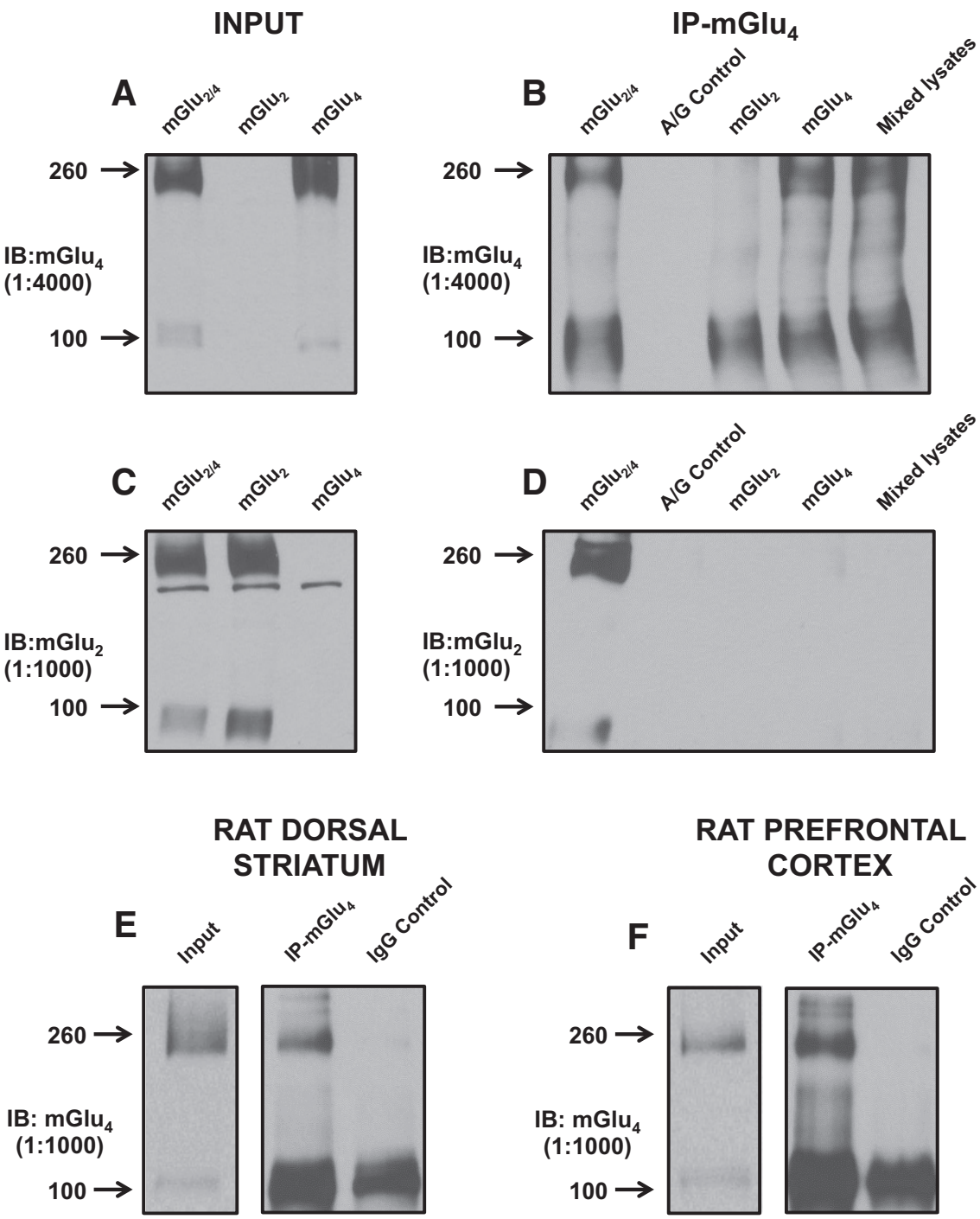

\section{RAT DORSAL} STRIATUM
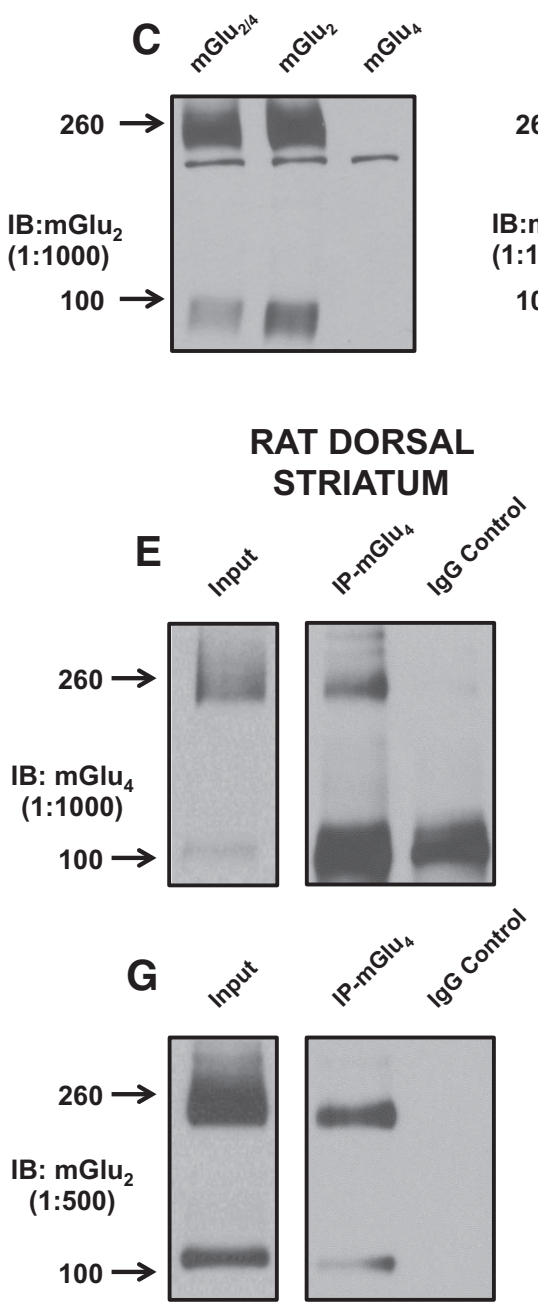

Figure 3. $\mathrm{mGlu}_{2}$ and $\mathrm{mGlu}_{4}$ are coimmunoprecipitated from HEK cells and rat dorsal striatum and medial prefrontal cortex. $\mathrm{mGlu}_{4}$ antibodies were used for coimmunoprecipitation. $\boldsymbol{A}-\boldsymbol{D}$. Cell lysates from $\mathrm{mGlu}_{2 / 4}, \mathrm{mGlu}_{2}$, and $\mathrm{mGlu}_{4}$ cell lines, together with lysates from $\mathrm{mGlu}_{2}$ cells and $\mathrm{mGlu}_{4}$ cells that were mixed after lysis, were subjected to immunoprecipitation experiments. Cell lysates from $\mathrm{mGlu}_{2 / 4}$ cells were also precipitated by protein $\mathrm{A} / \mathrm{G}$ beads without antibody as a negative control (A/G control). $\boldsymbol{E}-\boldsymbol{H}$, Dorsal striatum and medial prefrontal cortex extracts from rat were prepared as described, and tissue lysates were precipitated using anti-mGlu ${ }_{4}$ antibody (immunoprecipitation- $\mathrm{mGlu}_{4}$ ) or rabbit $\lg \mathrm{G}(\mathrm{IgG}$ Control). The precipitated proteins were analyzed via Western blots and lysates before immunoprecipitation experiments were loaded as input. Molecular sizes of $\mathrm{mGlu}_{2}$ or $\mathrm{mGlu}_{4}(\sim 100 \mathrm{kDa}$ and $\sim 240 \mathrm{kDa}$ for monomeric and dimeric forms, respectively) are indicated with arrows.

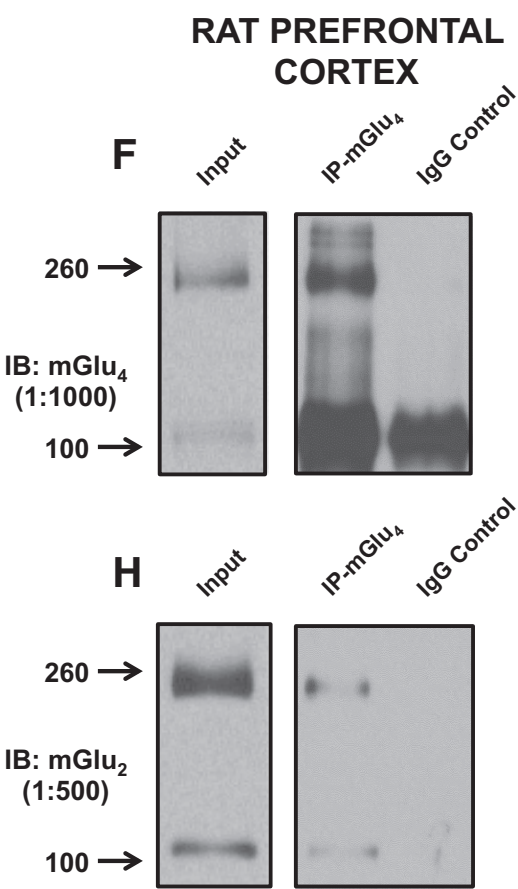

PHCCC fails to potentiate $\mathrm{mGlu}_{4}$ responses in the $\mathrm{mGlu}_{2 / 4}$ cell line

To further test the hypothesis that the lack of efficacy of PHCCC at corticostriatal synapses was due to expression of $\mathrm{mGlu}_{4}$ 
A

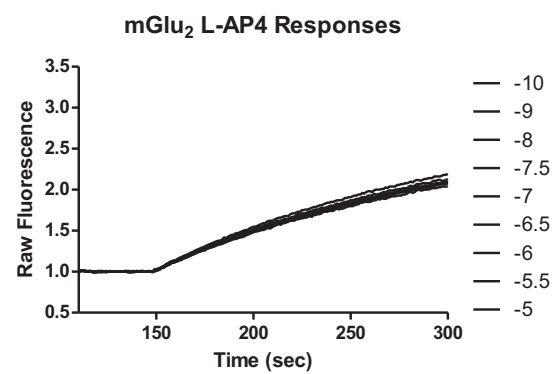

D

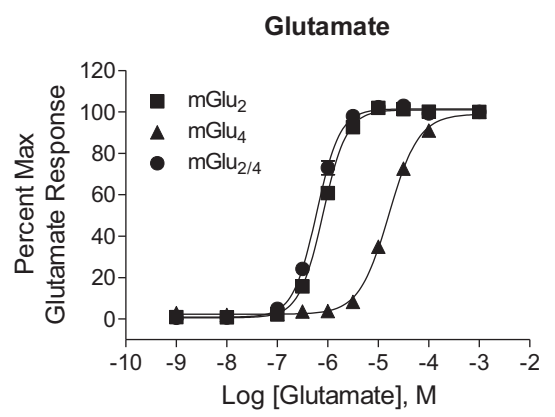

B

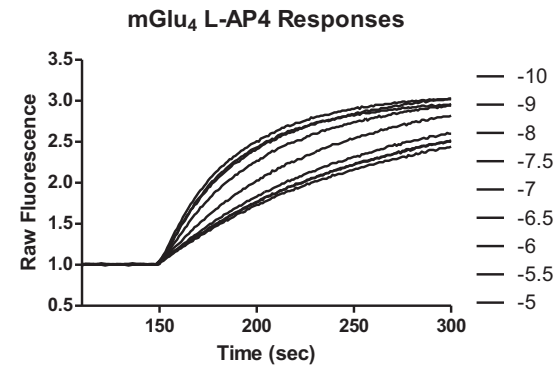

E

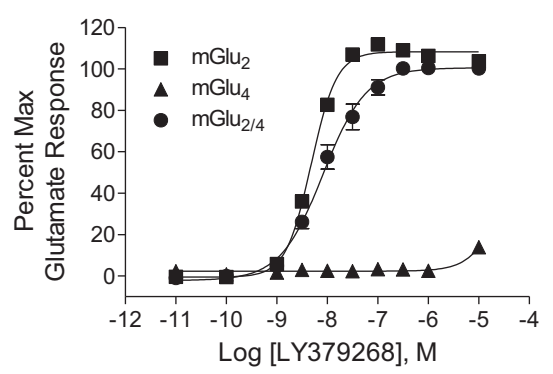

C

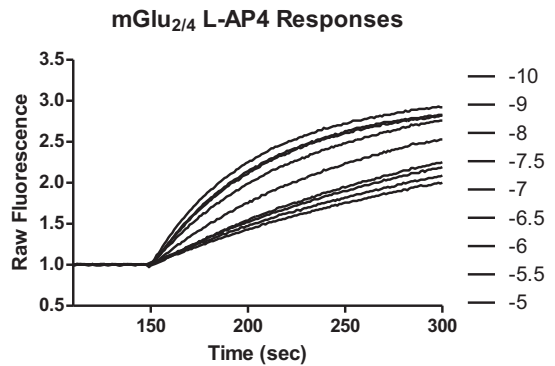

F

L-AP4

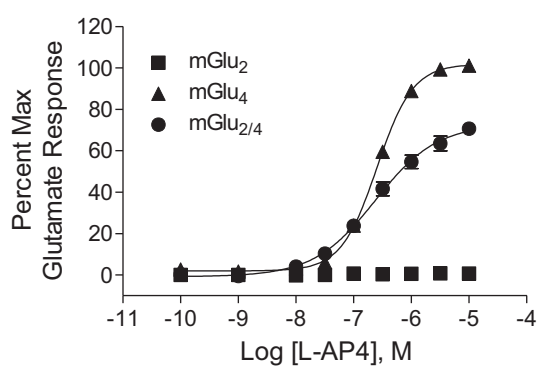

Figure 4. Orthosteric agonist responses are distinct in $\mathrm{mGlu}_{2}, \mathrm{mGlu}_{4}$, or $\mathrm{mGlu}_{2 / 4}$-expressing cell lines. $\boldsymbol{A}$-C, Sample traces of $\mathrm{L}-\mathrm{AP} 4$ responses in $\mathrm{mGlu}_{2}, \mathrm{mGlu}_{4}$, and $\mathrm{mGlu} \mathrm{u}_{2 / 4}$ cells with concentrations ranging from $0.1 \mathrm{~nm}$ to $10 \mu \mathrm{m}$. The initial slopes of the raw traces were used to generate concentration response curves shown in $\boldsymbol{F}$. $\boldsymbol{D}-\boldsymbol{F}$, Serial dilutions of glutamate $(\boldsymbol{D})$, the Group $\|$ agonist LY379268 (E), and the Group III agonist L-AP4 $(\boldsymbol{F})$ were applied to HEK/GIRK/mGlu $2(\boldsymbol{\square}), \mathrm{HEK} / \mathrm{GIRK} / \mathrm{mGlu}_{4}(\mathbf{\Delta})$, and HEK/GIRK/mGlu $2 / 4(\boldsymbol{\bullet})$ cell lines, and GIRK-mediated thallium flux was measured according to protocols described above. Reponses were normalized to the maximal response induced by $1 \mathrm{~mm}$ glutamate in each individual cell line, and pEC ${ }_{50}$ values for concentration-response curves are shown in Table 1. All values represent mean \pm SEM $(n \geq 3)$.

Table 1. Potencies and efficacies of orthosteric agonists in various cell lines ${ }^{a}$

\begin{tabular}{|c|c|c|c|c|c|c|c|c|c|}
\hline & \multicolumn{3}{|l|}{$\mathrm{mGlu}_{2}$} & \multicolumn{3}{|l|}{$\mathrm{mGlu}_{4}$} & \multicolumn{3}{|l|}{$\mathrm{mGlu}_{2 / 4}$} \\
\hline & $\mathrm{pEC}_{50}$ & \% Glu Max & Hill slope & $\mathrm{pEC}_{50}$ & \% Glu Max & Hill slope & $\mathrm{pEC} \mathrm{C}_{50}$ & \% Glu Max & Hill slope \\
\hline tamate & $6.08 \pm 0.03$ & $101.0 \pm 0.8$ & $1.88 \pm 0.08$ & $4.79 \pm 0.03$ & $99.1 \pm 0.5$ & $1.50 \pm 0.03$ & $6.22 \pm 0.03^{b}$ & $101.4 \pm 0.6$ & $2.01 \pm 0.04$ \\
\hline LY379268 & $8.32 \pm 0.02$ & $108.3 \pm 0.9$ & $1.73 \pm 0.05$ & $>5.0$ & NA & NA & $8.04 \pm 0.10^{c}$ & $101.9 \pm 0.9^{d}$ & $1.10 \pm 0.10^{e}$ \\
\hline L-AP4 & NA & NA & NA & $6.60 \pm 0.03$ & $100.9 \pm 1.1$ & $1.42 \pm 0.03$ & $6.64 \pm 0.05$ & $72.8 \pm 2.0^{f}$ & $0.91 \pm 0.02^{g}$ \\
\hline
\end{tabular}

${ }^{a}$ Data represent the mean \pm SEM of at least three experiments performed in duplicate. NA, Not applicable. $p$ values (unpaired Student's $t$ test; $n \geq 3$, two-tailed).

${ }^{b} p=0.0034$ for $m G l u_{2}$ versus $m G l u_{2 / 4}$ lines.

$c^{c} p=0.0161$ for $\mathrm{mGlu}_{2}$ versus $m G l u_{2 / 4}$ lines.

${ }^{d} p=0.0049$ for $\mathrm{mGlu}_{2}$ versus $\mathrm{mGlu}_{2 / 4}$ lines.

${ }^{e} p<0.0001$ for $\mathrm{mGlu}_{2}$ versus $\mathrm{mGlu}_{2 / 4}$ lines.

${ }^{f} p<0.0001$ for $\mathrm{mGlu}_{4}$ versus $\mathrm{mGlu}_{2 / 4}$ lines.

${ }^{g} p<0.0001$ for $\mathrm{mGlu}_{4}$ versus $\mathrm{mGlu}_{2 / 4}$ lines.

containing heteromers, the pharmacology of $\mathrm{mGlu}_{2 / 4}$ receptors was extensively characterized using the thallium flux assay (Niswender et al., 2008a). In these studies, the initial slopes (starting $5 \mathrm{~s}$ after thallium addition and then measured over a $10 \mathrm{~s}$ time span) of inward flux of thallium are calculated and plotted as agonist-induced concentration-response curves (samples traces of thallium flux assays are shown in Fig. $4 A-C$ and represent the data used to generate the L-AP4 curves in Fig. $4 F$ ). Glutamate, the orthosteric agonist for both $\mathrm{mGlu}_{2}$ and $\mathrm{mGlu}_{4}$, exhibited a potency in the $\mathrm{mGlu}_{2 / 4}$ cell line similar to that at $\mathrm{mGlu}_{2}$ (Fig. $4 D$; Table 1). To further characterize each of the subtypes in the hetero-complex, more selective agonists were used for $\mathrm{mGlu}_{2}$ (LY379268) or $\mathrm{mGlu}_{4}$ (L-AP4) (Fig. 4E,F). In the $\mathrm{mGlu}_{2 / 4}$ cell line, the $\mathrm{mGlu}_{2}$ agonist LY379268 elicited a full agonist response with a slightly reduced potency compared with cells expressing $\mathrm{mGlu}_{2}$ alone (Fig. 4E; Table 1). Likewise, L-AP4, the $\mathrm{mGlu}_{4}$ selective agonist, induced an agonist response with similar potency in cells expressing $\mathrm{mGlu}_{2 / 4}$ and $\mathrm{mGlu}_{4}$ alone. Unlike LY379268, L-AP4 was only able to elicit $\sim 70 \%$ of the maximum response generated by glutamate in $\mathrm{mGlu}_{2 / 4}$ cells. Additionally, we observed a significant decrease in the Hill slope of the curve fits for both LY379268 and L-AP4 in mGlu $_{2 / 4}$-coexpressing cells (Table 1 ), indicating an interaction between the two proteins and supporting the hypothesis that the $\mathrm{mGlu}_{2 / 4}$ complex possesses distinct pharmacological properties.

After assessing the activity of orthosteric agonists in cells expressing either receptor alone or expressing the combination, we moved to an analysis of potential effects on the pharmacology of allosteric modulators for $\mathrm{mGlu}_{4}$ and $\mathrm{mGlu}_{2}$ (structures shown in Fig. 5). Advantages of focusing our studies on $\mathrm{mGlu}_{2}$ and $\mathrm{mGlu}_{4}$ are as follows: (1) these receptors are coexpressed in many brain regions, and (2) there are a number of orthosteric and allosteric ligands that differentiate between $\mathrm{mGlu}_{2}$ and $\mathrm{mGlu}_{4}$, allowing us to generate a tool set of ligands appropriate for native tissue stud- 
ies. For these studies, PHCCC and other PAMs were added 2 min before the addition of glutamate or other orthosteric agonists. As expected, $10 \mu \mathrm{M}$ PHCCC induced a significant leftward fold shift of the L-AP4 response in cells expressing $\mathrm{mGlu}_{4}$ alone (Fig. 6A; Table 2). In contrast, $\mathrm{PHCCC}$ induced a negligible shift of the $\mathrm{L}-\mathrm{AP} 4$ response in the $\mathrm{mGlu}_{2 / 4}$ cell line (Fig. 6B; Table 2). When assessed using glutamate, $10 \mu \mathrm{M}$ PHCCC shifted the concentration-response curve to the left by $3.5 \pm 0.53$-fold in $\mathrm{mGlu}_{4}$ cells (Fig. $6 C$ ) but did not potentiate the glutamate response in cells expressing both $\mathrm{mGlu}_{2}$ and $\mathrm{mGlu}_{4}$ (Fig. 6D; Table 2). This loss of efficacy in the $\mathrm{mGlu}_{2 / 4}$ cell line is consistent with a previous report (Kammermeier, 2012) and aligns with the lack of significant potentiation of the L-AP4 response we observed with PHCCC at corticostriatal synapses (Fig. 1C). The inability to potentiate $\mathrm{mGlu}_{2 / 4}$ heteromers was not limited to PHCCC alone. 4PAM-2 is a selective and efficacious PAM of $\mathrm{mGlu}_{4}$, which binds to the same allosteric site as PHCCC (Drolet et al., 2011). In cells expressing $\mathrm{mGlu}_{4}$ alone, $10 \mu \mathrm{M}$ 4PAM-2 shifted concentration-response curves of L-AP4 and glutamate by $18.8 \pm 2.6$ and $15.2 \pm 3.1$-fold, respectively. When $\mathrm{mGlu}_{2}$ was coexpressed, however, 4-PAM2 only weakly potentiated the L-AP4 response and was completely ineffective at shifting the glutamate concentration-response curve (Table 2).

\section{The $\mathrm{mGlu}_{4}$ PAM VU0155041 exhibits enhanced potentiation when $\mathrm{mGlu}_{2}$ is present}

VU0155041 is another $\mathrm{mGlu}_{4}$ PAM derived from a different chemical scaffold compared with PHCCC or 4PAM-2. Consistent with our previous report (Niswender et al., 2008b), VU0155041 (10 $\mu \mathrm{M})$ shifted the L-AP4 and glutamate concentration-response curves to the left by $3.9 \pm 0.3$ and $4.0 \pm 0.3$-fold, respectively, in cells expressing $\mathrm{mGlu}_{4}$ alone (Figs. 6E, $G$ ). Interestingly, VU0155041 also induced leftward shifts in the agonist concentration response curves in the $\mathrm{mGlu}_{2 / 4}$ cell line, shifting the L-AP4 response substantially $(9.7 \pm 1.0$-fold shift $)$, retaining its efficacy in shifting the glutamate response $(3.5 \pm 0.3$-fold shift) (Fig. $6 F, H)$, and, surprisingly, even showing significant potentiation of the LY379268 response (Table 2). It should be noted that we did not observe any activity of VU0155041 when mGlu was expressed alone, suggesting that the enhanced ability of VU0155041 to potentiate L-AP4 responses when $\mathrm{mGlu}_{2}$ and $\mathrm{mGlu}_{4}$ are both present does not appear to be the result of nonselective activity of VU0155041 at $\mathrm{mGlu}_{2}$ receptors (Table 2) (Niswender et al., 2008b). As VU0155041 is predicted to bind only to the $\mathrm{mGlu}_{4}$ protein and LY379268 should only activate $\mathrm{mGlu}_{2}$, this finding suggests that there is transactivation between the subunits within the heteromer.

We also noted a slight decrease in the maximal response induced by the VU0155041/glutamate combination in cells expressing $\mathrm{mGlu}_{2 / 4}$ (Fig. $6 \mathrm{H}$ ); this was not present when L-AP4 was used as the agonist (Fig. $6 F$ ) or when $\mathrm{mGlu}_{4}$ was expressed alone (Fig. 6G). There are several possibilities that may explain this phenomenon. There could be differences in receptor desensitiza-
$\mathrm{mGlu}_{2}$ PAMs<smiles>Cc1c(OCc2cccc(-c3ccc(C(=O)O)cc3)c2)cc2c(c1C)C(=O)C(C1CCCC1)C2</smiles>

4PAM-2

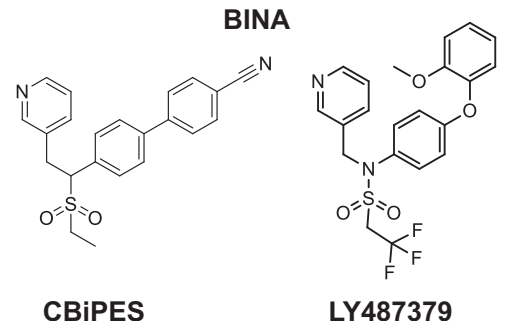

Lu AF21934

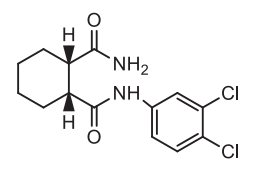

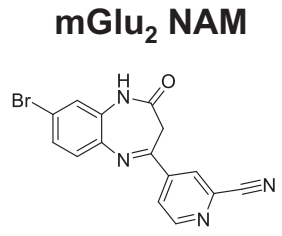

MNI-137

Figure 5. Structures of allosteric ligands used in these studies.

tion induced by the allosteric agonist activity of VU0155041 (Niswender et al., 2008b). When the agonist activity of VU0155041 was assessed in the absence of orthosteric agonist, the potency of VU0155041 was similar in cells expressing mGlu $_{4}$ versus those containing $\mathrm{mGlu}_{2 / 4}$ as was the maximal level of potentiation $\left(\mathrm{pEC}_{50}\right.$ value, $\mathrm{mGlu}_{4}, 5.38 \pm 0.17$, and $\mathrm{mGlu}_{2 / 4}$ cells, $5.25 \pm 0.10$, $p=0.5719$; maximal response, $\mathrm{mGlu}_{4}, 40.5 \pm 4.8 \%$ of glutamate maximal response, and $\mathrm{mGlu}_{2 / 4}$ cells, $38.9 \pm 6.3 \%$ of glutamate maximal response, $p=0.8459$ ), suggesting that differential desensitization is not the cause of this discrepancy. It is possible that the use of glutamate in these experiments may contribute to this change in maximal response as glutamate will activate both $\mathrm{mGlu}_{2}$ and $\mathrm{mGlu}_{4}$. The decrease in the maximal response occurs at glutamate concentrations that would activate both $\mathrm{mGlu}_{2}$ and $\mathrm{mGlu}_{4}$, suggesting that there could be unique responses elicited when both the $\mathrm{mGlu}_{2}$ and $\mathrm{mGlu}_{4}$ orthosteric sites are occupied. The use of L-AP4, however, would not carry such a caveat, and the maximal responses in Figure $6 F$ are similar with or without VU0155041. Regardless of mechanism, these results reveal that VU0155041 can be used as a chemical probe to potentiate responses to activation of $\mathrm{mGlu}_{2 / 4}$ heterodimers.

The marked distinction between VU0155041 and PHCCC led us to speculate that the divergence in effect between the two PAMs may arise from their different chemical structures or binding sites; PHCCC and 4-PAM2 have been reported to bind to the same site on $\mathrm{mGlu}_{4}$, whereas VU0155041 appears to bind to a distinct site on the $\mathrm{mGlu}_{4}$ protein (Drolet et al., 2011), assessed using a racemic mixture of VU0155041 regioisomers. Consistent with this hypothesis, the VU0155041-related compound, Lu AF21934, also exhibited an enhanced ability to potentiate L-AP4 responses and retained the ability to potentiate glutamate responses in cells coexpressing both receptors (Table 2). To gain further insight into the mechanism of these pharmacological changes, the ability of increasing amounts of compound to induce progressive leftward shifts in agonist concentration-re- 
PHCCC
$\mathrm{mGlu}_{4}$ cells
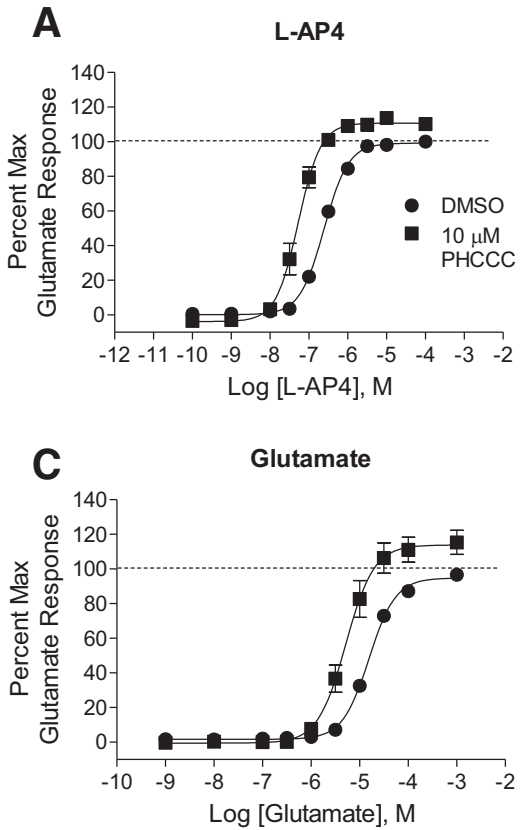

$\mathrm{mGlu}_{2 / 4}$ cells

B

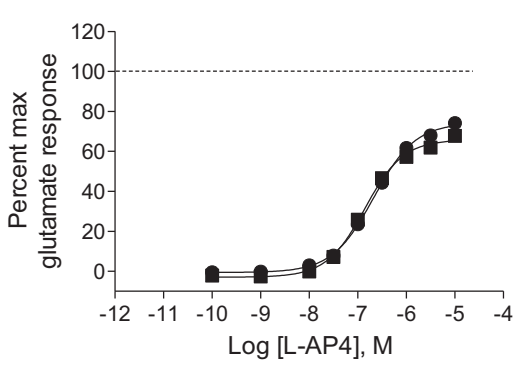

D Glutamate

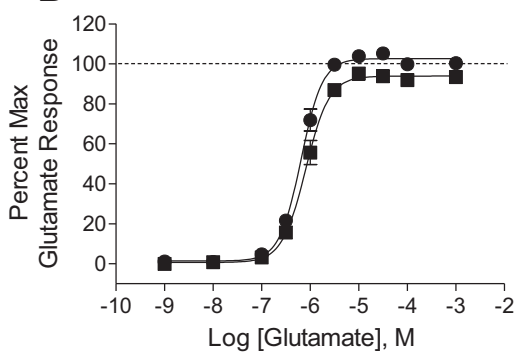

sponse curves was measured using each individual $\mathrm{mGlu}_{4}$ PAM, and the operational model of allosterism was applied to compare the affinity $\left(\log \mathrm{K}_{\mathrm{B}}\right)$ and cooperativity ( $\log \alpha \beta$-a combined parameter that represents the effects of a modulator on affinity $(\alpha)$ as well as effects on efficacy $(\beta))$ of PAMs in cells expressing $\mathrm{mGlu}_{4}$ alone versus $\mathrm{mGlu}_{2 / 4}$. As shown in Table 3 , the estimated affinity of PHCCC was similar in $\mathrm{mGlu}_{2 / 4}$ cells compared with cells expressing $\mathrm{mGlu}_{4}$ alone. However, the positive cooperativity of PHCCC decreased significantly in the $\mathrm{mGlu}_{2 / 4}$ cell line $(p=0.0017)$. Similar to PHCCC, 4PAM-2 also demonstrated a significant decrease in positive cooperativity in mGlu $_{2 / 4}$ cells; again, the affinity of the compound was not significantly different in the cell line expressing both receptors (Table 3). In contrast, VU0155041 and Lu AF21934 exhibited significant changes in affinity as well as increases in positive cooperativity in $\mathrm{mGlu}_{2 / 4}$-expressing cells compared with cells expressing $\mathrm{mGlu}_{4}$ alone (Table 3 ).

\section{VU0155041}

\section{$\mathrm{mGlu}_{4}$ cells}

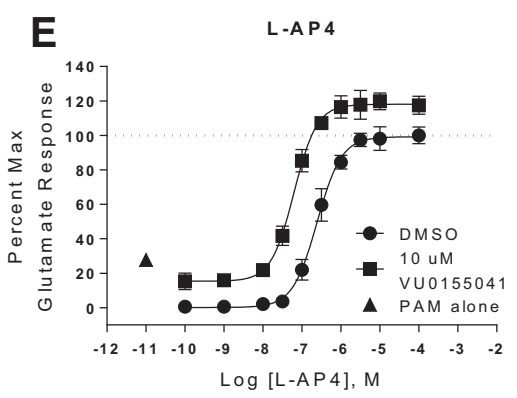

G

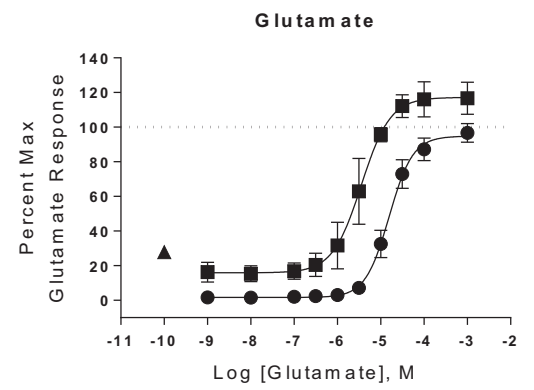

$\mathrm{mGlu}_{2 / 4}$ cells

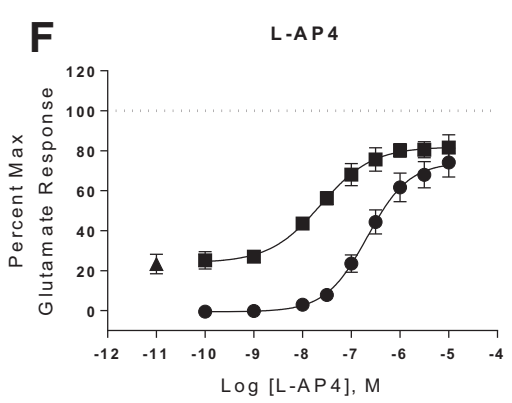

H

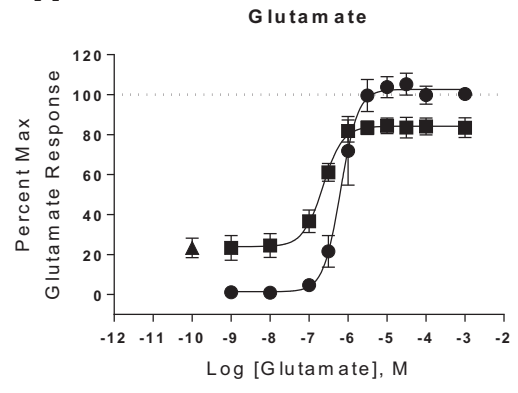

Figure 6. The efficacies of $\mathrm{PHCCC}$ and VU0155041 are differentially regulated by $\mathrm{mGlu} \mathrm{u}_{2 / 4}$ coexpression. $\boldsymbol{A}-\boldsymbol{H}$, A total of 10 $\mu \mathrm{M}$ compound $(\mathbf{\square})$ or DMSO $(\mathbf{O})$ was added $140 \mathrm{~s}$ before addition of serial dilutions of L-AP4 or glutamate. Allosteric agonist activity of $10 \mu \mathrm{m}$ VU0155041 was determined using PAM alone in the absence of L-AP4 or glutamate ( $\mathbf{\Delta})$. GIRK channel-mediated thallium flux was measured as described in $\mathrm{HEK} / \mathrm{GIRK} / \mathrm{mGlu}_{4}$ (left panels) and HEK/GIRK/mGlu 2/4 $_{4}$ (right panels) cell lines. Reponses were normalized to the maximal response induced by $1 \mathrm{~mm}$ glutamate in each individual cell line. $\mathrm{pEC}_{50}$ values for dose-response curves in $\boldsymbol{A}-\boldsymbol{D}$ without or with $\mathrm{PHCCC}$ were as follows: $\boldsymbol{A}, 6.61 \pm 0.11$ versus $7.28 \pm$ $0.11(p=0.0115) ; \boldsymbol{B}, 6.63 \pm 0.06$ versus $6.85 \pm 0.05(p=0.0557) ; \boldsymbol{C}, 4.77 \pm 0.05$ versus $5.27 \pm 0.10(p=0.0017)$; $\boldsymbol{D}, 6.11 \pm 0.05$ versus $6.09 \pm 0.06(p=0.8383)$. $\mathrm{pEC}_{50}$ values for dose-response curves in $\boldsymbol{E}-\boldsymbol{H}$ without or with VU0155041 were as follows: $\boldsymbol{E}, 6.61 \pm 0.11$ versus $7.21 \pm 0.08(p=0.0113) ; \boldsymbol{F}, 6.63 \pm 0.06$ versus $7.61 \pm 0.07$ ( $p=$ $0.0004) ; \boldsymbol{G}, 4.77 \pm 0.05$ versus $5.36 \pm 0.04(p<0.0001) ; \boldsymbol{H}, 6.11 \pm 0.05$ versus $6.64 \pm 0.02(p<0.0001)$. All values represent mean $\pm \operatorname{SEM}(n \geq 3)$.
Expression of different levels of $\mathrm{mGlu}_{2}$ relative to $\mathrm{mGlu}_{4}$ regulates the efficacy of $\mathrm{mGlu}_{4}$ PAMs

The lack of efficacy of PHCCC and 4PAM-2 suggests that the $\mathrm{mGlu}_{2 / 4}$ cell line in which we performed our studies contains few or no $\mathrm{mGlu}_{4}$ homomers, indicating that $\mathrm{mGlu}_{2 / 4}$ interactions may be dominant and actually preferred. To further probe the interactions between the receptors, we transiently transfected either increasing amounts of $\mathrm{mGlu}_{2}$ alone, increasing amounts of $\mathrm{mGlu}_{2}$ in the presence of a constant amount of $\mathrm{mGlu}_{4}$, or increasing amounts of $\mathrm{mGlu}_{2}$ in the presence of another Group III mGlu, mGlu $\mathrm{mGlu}_{7}$ was chosen as Kammermeier (2012) previously reported that $\mathrm{mGlu}_{2}$ and $\mathrm{mGlu}_{7}$ do not appear to interact in the same fashion as $\mathrm{mGlu}_{2}$ and $\mathrm{mGlu}_{4}$, suggesting that there is some specificity to the interaction. In these studies, we observed gradual increases in the maximal LY379268 response when $\mathrm{mGlu}_{2}$ was expressed alone in increasing amounts (data not shown); at the concentrations used here, we saw no significant differences in the potency (Fig. 7A) or Hill slope (Fig. $7 B$ ) of the LY379268 response when $\mathrm{mGlu}_{2}$ was assessed in the absence of other mGlus. In the presence of $\mathrm{mGlu}_{7}$, responses appeared similar to those in which $\mathrm{mGlu}_{2}$ alone was expressed, with no differences in LY379268 potency or Hill slope (Fig. $7 A, B)$. In the presence of $\mathrm{mGlu}_{4}$, however, the potency of LY379268 was pro- 
Table 2. The ability of mGlu ${ }_{4}$ PAMs to left-shift agonist concentration-response curves is distinct for different groups of PAMs ${ }^{a}$

\begin{tabular}{|c|c|c|c|c|c|c|c|}
\hline & \multicolumn{2}{|l|}{$\mathrm{mGlu}_{2}$} & \multicolumn{2}{|l|}{$\mathrm{mGlu}_{4}$} & \multicolumn{3}{|l|}{$\mathrm{mGlu}_{2 / 4}$} \\
\hline & Glutamate & LY379268 & Glutamate & L-AP4 & Glutamate & LY379268 & L-AP4 \\
\hline $10 \mu \mathrm{M} \mathrm{PHCCC}$ & $0.9 \pm 0.03$ & $1.0 \pm 0.04$ & $3.5 \pm 0.53$ & $4.7 \pm 0.02$ & $1.0 \pm 0.04^{b}$ & $0.8 \pm 0.07$ & $1.7 \pm 0.04^{c}$ \\
\hline $10 \mu \mathrm{M}$ 4РАМ-2 & $0.9 \pm 0.03$ & $0.9 \pm 0.05$ & $15.2 \pm 3.10$ & $18.8 \pm 2.58$ & $1.0 \pm 0.02^{d}$ & $0.9 \pm 0.07$ & $2.7 \pm 0.21^{e}$ \\
\hline $10 \mu \mathrm{m}$ VU0155041 & $0.9 \pm 0.02$ & $0.9 \pm 0.02$ & $4.0 \pm 0.26$ & $3.9 \pm 0.29$ & $3.5 \pm 0.30$ & $4.1 \pm 0.12^{f}$ & $9.7 \pm 1.00^{g}$ \\
\hline $10 \mu \mathrm{m}$ Lu AF21934 & $1.0 \pm 0.03$ & $1.0 \pm 0.02$ & $3.4 \pm 0.14$ & $3.9 \pm 0.08$ & $2.7 \pm 0.17^{h}$ & $1.7 \pm 0.10^{i}$ & $8.2 \pm 0.96^{j}$ \\
\hline
\end{tabular}

${ }^{a}$ Data represent the mean \pm SEM of at least three experiments performed in duplicate. $p$ values (unpaired Student's $t$ test; $n \geq 3$, two-tailed). There is the ability of VU0155041 to shift responses of the mGlu ${ }_{2}$ agonist LY379268.

${ }^{b} p=0.0009$ for $\mathrm{mGlu}_{4}$ versus $\mathrm{mGlu}_{2 / 4}$ lines.

${ }^{c} p<0.0001$ for $\mathrm{mGlu}_{4}$ versus $\mathrm{mGlu}_{2 / 4}$ lines.

${ }_{p}=0.0003$ for $\mathrm{mGlu}_{4}$ versus $\mathrm{mGlu} \mathrm{u}_{2 / 4}$ lines.

$e_{p}=0.0034$ for $\mathrm{mGlu}_{4}$ versus $\mathrm{mGlu}_{2 / 4}$ lines.

${ }_{p} p<0.0001$ for $\mathrm{mGlu}_{2}$ versus $\mathrm{mGlu}_{2 / 4}$ lines.

${ }^{g} p=0.0054$ for $\mathrm{mGlu}_{4}$ versus $m \mathrm{mGlu}_{2 / 4}$ lines.

${ }^{h} p=0.0175$ for $\mathrm{mGlu}_{4}$ versus $\mathrm{mGlu}_{2 / 4}$ lines.

${ }^{i} p<0.0001$ for $\mathrm{mGlu}_{2}$ versus $\mathrm{mGlu}_{2 / 4}$ lines.

${ }^{j} p=0.0021$ for $\mathrm{mGlu}_{4}$ versus $\mathrm{mGlu}_{2 / 4}$ lines.

Table 3. Analysis of $\mathrm{mGlu}_{4}$ PAMs using the operational model of allosterism reveals differential alterations in affinity or cooperativity for distinct groups of PAMs ${ }^{a}$

\begin{tabular}{|c|c|c|c|c|}
\hline & \multicolumn{2}{|l|}{$\log K_{B}$} & \multicolumn{2}{|l|}{$\log \alpha \beta$} \\
\hline & $\mathrm{mGlu}_{4}$ cells & $\mathrm{mGlu}_{2 / 4}$ cells & $\mathrm{mGlu}_{4}$ cells & $\mathrm{mGlu}_{2 / 4}$ cells \\
\hline Hece & -5.4 & $-5.47 \pm 0.09$ & $0.94 \pm 0.06$ & $0.51 \pm 0.01^{b}$ \\
\hline 4PAM-2 & $-6.32 \pm 0.04$ & $-6.44 \pm 0.06$ & $1.29 \pm 0.04$ & $0.82 \pm 0.02^{c}$ \\
\hline VU0155041 & $-5.27 \pm 0.01$ & $-4.78 \pm 0.13^{d}$ & $0.95 \pm 0.05$ & $1.83 \pm 0.27^{e}$ \\
\hline Lu AF21934 & $-5.88 \pm 0.04$ & $-5.26 \pm 0.09^{f}$ & $0.66 \pm 0.03$ & $1.70 \pm 0.11^{g}$ \\
\hline
\end{tabular}

${ }^{a}$ Data were generated by progressive fold shift experiments using increasing concentrations of four mGlu ${ }_{4}$ PAMs (ranging from 0 to $30 \mu \mathrm{m}$ ) before application of a full concentration-response range of L-AP4 (ranging from $0.1 \mathrm{nM}$ to $10 \mu \mathrm{M}$ ). The $\log _{\mathrm{A}}$ of $\mathrm{L}-\mathrm{AP} 4$ for $\mathrm{mGlu}_{4}$ was set to -6.759 according to literature values (Monastyrskaia et al., 1999). For PHCCC and $4 P A M-2, \log \tau_{\mathrm{B}}$ was set to -100 because of the lack of allosteric agonist activity but was allowed to float for compounds exhibiting allosteric agonism (VU0155041, Lu-AF29134). Data represent the mean \pm SEM of at least three experiments performed in duplicate. $p$ values (unpaired Student's $t$ test; $n \geq 3$, two-tailed).

${ }^{b} p=0.0017$ between $\mathrm{mGlu}_{4}$ cells and $m G \mathrm{u}_{2 / 4}$ cells.

${ }^{c} p=0.0006$ between $\mathrm{mGlu}_{4}$ cells and $\mathrm{mGlu}_{2 / 4}$ cells.

${ }^{d} p=0.0188$ between $\mathrm{mGlu}_{4}$ cells and $\mathrm{mGlu}_{2 / 4}$ cells.

$e_{p}=0.0334$ between $\mathrm{mGlu}_{4}$ cells and $\mathrm{mGlu}_{2 / 4}$ cells.

${ }^{f} p=0.0042$ between $\mathrm{mGlu}_{4}$ cells and $\mathrm{mGlu}_{2 / 4}$ cells.

${ }^{g} p=0.0008$ between $\mathrm{mGlu}_{4}$ cells and $\mathrm{mGlu}_{2 / 4}$ cells.

gressively shifted to the left when $\mathrm{mGlu}_{2}$ levels were increased; additionally, the Hill slope of the curve fit also progressively increased, indicating alterations in cooperativity between the subunits. These differences suggest that the $\mathrm{mGlu}_{2 / 4}$ combination appears to be distinct from that of $\mathrm{mGlu}_{2 / 7}$, indicating some specificity in this interaction and confirming previous work (Kammermeier, 2012).

We next tested the activity of $\mathrm{mGlu}_{4}$ PAMs after transient transfection of increasing amounts of $\mathrm{mGlu}_{2}$ in the presence of a constant amount of $\mathrm{mGlu}_{4}$. In these experiments, a $30 \mu \mathrm{M}$ concentration of each PAM was used. In cells transfected with just $\mathrm{mGlu}_{4}, 30 \mu \mathrm{M}$ of PHCCC induced $7.2 \pm 1.5$ and $8.5 \pm 0.3$-fold leftward shifts of the glutamate or L-AP4 concentration-response curves, respectively. However, in cells cotransfected with $0.1,0.2$, and $0.5 \mu \mathrm{g} \mathrm{mGlu}{ }_{2}$ DNA, the shift of the L-AP4 response progressively decreased, and in cells transfected with equal amounts of $\mathrm{mGlu}_{2}$ and $\mathrm{mGlu}_{4}$, the shift was only $1.9 \pm 0.5$-fold (Fig. 7C). In addition, the shift of the glutamate response, even with only 0.1 $\mu \mathrm{g}$ of $\mathrm{mGlu}_{2}$ DNA present $\left(10 \%\right.$ of the amount of $\left.\mathrm{mGlu}_{4}\right)$, drastically decreased to only $1.3 \pm 0.1$-fold (Fig. $7 D$ ), suggesting a quite dramatic and dominant effect induced by the presence of $\mathrm{mGlu}_{2}$. As with the responses observed with PHCCC, 4PAM-2 demonstrated similar efficacy changes in transiently transfected cells, which is consistent with our findings in the stable cell lines and the observation that these two PAMs bind to the same allosteric pocket. Interestingly, the potentiation induced by VU0155041 and Lu AF21934 remained similar as the amount of $\mathrm{mGlu}_{2}$ increased, further supporting the observation that distinct classes of $\mathrm{mGlu}_{4}$ PAMs are differentially regulated by $\mathrm{mGlu}_{2 / 4}$ interactions. It should be noted, in these experiments, that the similarity in potencies and Hill slopes of LY379268 in mGlu $_{2 / 4}$-expressing cells when the $\mathrm{mGlu}_{2: 4}$ ratio is $1: 1$, compared with cells expressing $\mathrm{mGlu}_{2}$ alone, suggests that $\mathrm{mGlu}_{2}$ homomers may exist along with $\mathrm{mGlu}_{2 / 4}$ heteromers in these experiments. In contrast, our data also suggest that $\mathrm{mGlu}_{2 / 4}$ heteromers are the dominant entity for $\mathrm{mGlu}_{4}$ in these experiments. This interpretation is supported by the lack of potentiation induced by PHCCC and 4 PAM-2 when glutamate is used as the agonist and the ratio of $\mathrm{mGlu}_{2}$ to $\mathrm{mGlu}_{4}$ is $1: 10$, suggesting that coexpression of even small amounts of $\mathrm{mGlu}_{2}$ dramatically regulates activity of $\mathrm{mGlu}_{4}$.

\section{Hetero-interaction of $\mathrm{mGlu}_{2 / 4}$ also impacts the effects of mGlu $_{2}$ allosteric modulators}

We also sought to investigate the influence of $\mathrm{mGlu}_{2 / 4}$ interaction on $\mathrm{mGlu}_{2}$ allosteric modulators. CBiPES and LY487379 are two PAMs from the pyridylmethylsulfonamide series that selectively potentiate $\mathrm{mGlu}_{2}$ (Johnson et al., 2003, 2005). More recently, another selective $\mathrm{mGlu}_{2}$ PAM, BINA, was identified from a different chemical scaffold (Galici et al., 2006). We took advantage of these structurally distinct compounds and compared their efficacy in cells expressing $\mathrm{mGlu}_{2}$ alone versus cells coexpressing $\mathrm{mGlu}_{2}$ and $\mathrm{mGlu}_{4}$. None of the $\mathrm{mGlu}_{2}$ PAMs potentiated responses to the $\mathrm{mGlu}_{4}$ agonist L-AP4 in either $\mathrm{mGlu}_{4}$ or $\mathrm{mGlu}_{2 / 4^{-}}$ expressing cells (data not shown). A total of $1 \mu \mathrm{M}$ BINA induced a $6.7 \pm 0.6$-fold leftward shift of the glutamate concentrationresponse curve in $\mathrm{mGlu}_{2}$ cells. However, this number significantly decreased, to $3.0 \pm 0.5$-fold, in cells expressing $\mathrm{mGlu}_{2 / 4}$ $(p=0.0003)$. Likewise, the ability of BINA to shift the LY379268 response significantly decreased from $4.0 \pm 1.1$-fold in $\mathrm{mGlu}_{2}$ cells to $1.7 \pm 0.2$-fold in $\mathrm{mGlu}_{2 / 4}$ cells $(p=0.0466)$. In contrast,

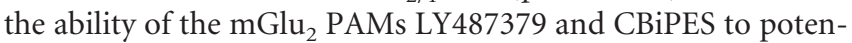
tiate either glutamate or LY379268 responses was not significantly altered. The fold shift values for LY487379 were $3.2 \pm 0.2$ ( $\mathrm{mGlu}_{2}$ cells) versus $2.7 \pm 0.3\left(\mathrm{mGlu}_{2 / 4}\right.$ cells $)$ with glutamate and $2.1 \pm 0.3$ versus $2.1 \pm 0.3$ with LY379268, respectively. The potentiation by CBiPES was $6.2 \pm 0.3$ versus $5.1 \pm 0.3$ with glutamate and $3.0 \pm 0.02$ versus $2.8 \pm 0.7$ with LY379268. These data suggest that distinct $\mathrm{mGlu}_{2}$ PAMs also possess different pharmacological profiles when $\mathrm{mGlu}_{2}$ is expressed alone relative to when $\mathrm{mGlu}_{2}$ and $\mathrm{mGlu}_{4}$ are coexpressed. However, unlike PHCCC, 


\section{Potency of LY379268 Response}

A

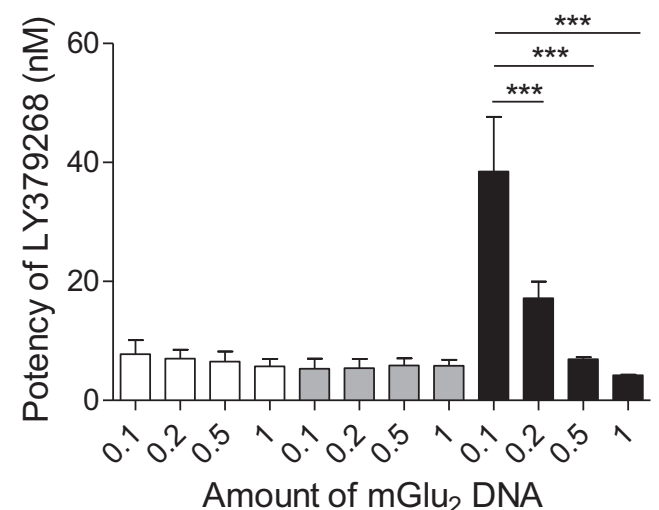

C

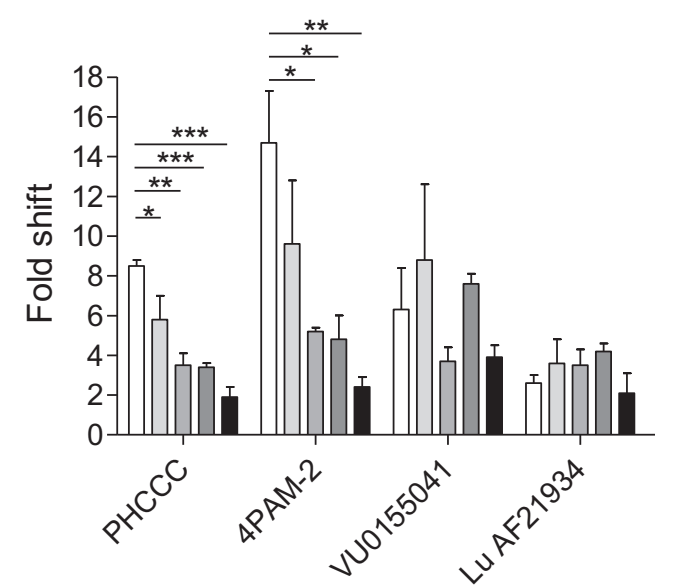

Hill slope of LY379268 Response

B

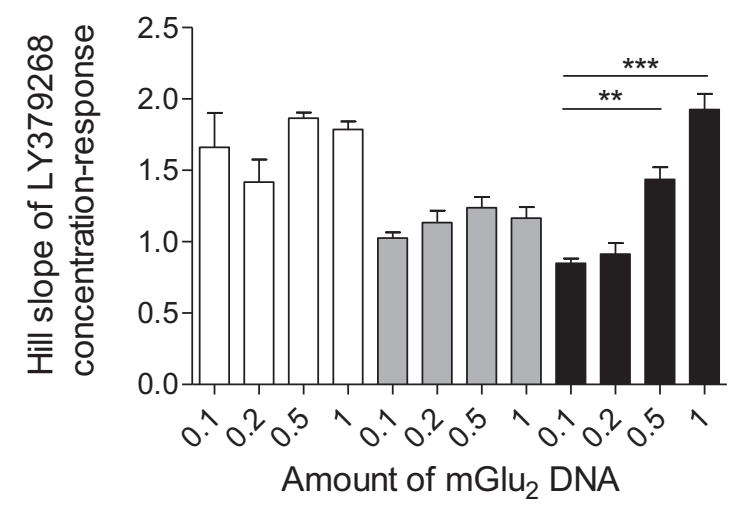

D

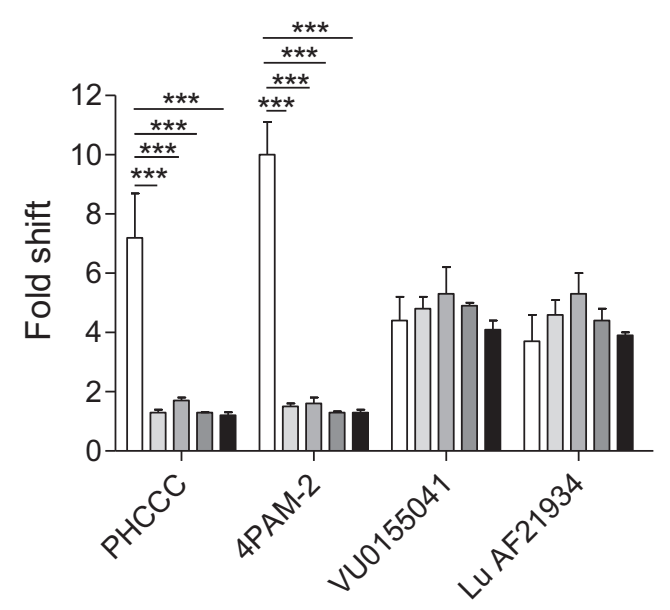

Figure 7. Coexpression of varying amounts of $\mathrm{mGlu}_{2}$ and $\mathrm{mGlu}{ }_{4}$ regulates responses to both orthosteric and allosteric ligands. HEK/GIRK cells were transfected with $0,0.1,0.2,0.5$, or $1 \mu \mathrm{g}$ mGlu 2 DNA in the absence or presence of cotransfection of $1 \mu \mathrm{g}$ of vector control, $1 \mu \mathrm{g} \mathrm{mGlu}$, or $1 \mu \mathrm{g} \mathrm{mGlu} 4 . A, B$, Potencies and Hill slope of the LY379268 response were determined; responses were unaffected by empty vector or $\mathrm{mGlu}_{7}$ but dramatically altered in the presence of $\mathrm{mGlu}_{4}$. C, D, The fold shifts induced by $30 \mu \mathrm{m}$ of PHCCC, 4 PAM-2, VU0155041, or Lu AF21934 are summarized for L-AP4 $(\boldsymbol{C})$ and glutamate $(\boldsymbol{D})$ using bar graphs. Fold shift values of glutamate responses in cells cotransfected with $0,0.1,0.2,0.5$, and 1 mGlu 2 were as follows: PHCCC: 7.2 $\pm 1.5,1.3 \pm 0.1,1.7 \pm 0.1$, $1.3 \pm 0.01$, and 1.2 \pm 0.1 -fold; 4 PAM-2: $10.0 \pm 1.1,1.5 \pm 0.1,1.6 \pm 0.2,1.3 \pm 0.04$, and1.3 \pm 0.1 -fold; VU0155041:4.4 $\pm 0.8,4.8 \pm 0.4,5.3 \pm 0.9,4.9 \pm 0.1$, and 4.1 \pm 0.3 -fold; Lu AF21934: $3.7 \pm 0.9,4.6 \pm 0.5,5.3 \pm 0.7,4.4 \pm 0.4$, and $3.9 \pm 0.1$-fold. Fold shift values of $\mathrm{L}-\mathrm{AP} 4$ responses were as follows: PHCCC: $8.5 \pm 0.3,5.8 \pm 1.2,3.5 \pm 0.6,3.4 \pm 0.2$, and 1.9 \pm 0.5 -fold; 4 PAM2: $14.7 \pm 2.6,9.6 \pm 3.2,5.2 \pm 0.2,4.8 \pm 1.2$, and 2.4 \pm 0.5 -fold; VU0155041:6.3 $\pm 2.1,8.8 \pm 3.8,3.7 \pm 0.7,7.6 \pm 0.5$, and 3.9 \pm 0.6 -fold; Lu AF21934:2.6 $\pm 0.4,3.6 \pm 1.2,3.5 \pm 0.8,4.2 \pm$ 0.4 , and $2.1 \pm 1.0$-fold, respectively. Values represent mean \pm SEM $(n=3)$. Statistics were performed using one-way ANOVA. $\boldsymbol{A}, \boldsymbol{B}$, Bonferroni's multiple-comparison test. $\boldsymbol{C}, \boldsymbol{D}$, Dunnett's multiple-comparison test. ${ }^{*} p<0.05 .{ }^{* *} p<0.01$. ${ }^{* * *} p<0.001$.

all $\mathrm{mGlu}_{2}$ PAMs evaluated had some activity at both $\mathrm{mGlu}_{2}$ and $\mathrm{mGlu}_{2 / 4}$, suggesting that either these cells express some level of homomeric $\mathrm{mGlu}_{2}$ or that the effect on potentiation is not as dramatic as that observed with the $\mathrm{mGlu}_{4}$ PAMs examined thus far. In contrast to what was observed with VU0155041/Lu AF21934 and their ability to potentiate LY379268 responses, we did not see potentiation of L-AP4 responses with any of the $\mathrm{mGlu}_{2}$ PAMs. Each of the $\mathrm{mGlu}_{2}$ PAMs used here exhibits similar potentiation of $\mathrm{mGlu}_{2}$ responses compared with the responses of VU0155041 and Lu AF21934 at mGlu 4 (3- to 6-fold), suggesting that our assay system should be sensitive enough to detect potentiation of an $\mathrm{mGlu}_{4}$ agonist response. However, in contrast to responses to $\mathrm{mGlu}_{4}$ agonists, we would note that there is possibly some masking of potentiation resulting from expression of $\mathrm{mGlu}_{2}$ homodimers in our cells. Each of the mGlu $\mathrm{m}_{2}$ PAMs used here shows some degree of allosteric agonist activity, which may complicate measurement of the signal when L-AP4 is used as the orthosteric agonist. In contrast to $\mathrm{mGlu}_{4}$, where we hypothesize most of the receptors are in heteromeric form, this may result in a loss of sensitivity. Additionally, these compounds could be engaging distinct sites on each receptor that translate to distinct abilities to induce potentiation. Our data actually are most consistent with the hypothesis that the two halves of the heteromer may not function symmetrically or may differentially interact with signaling components, such as G-proteins. If correct, this might suggest that one half of the dimer may be more sensitive to potentiation (or antagonism). Although this remains to be determined experimentally for $\mathrm{mGlu}_{2 / 4}$ heteromers and will require an assay system in which absolutely no $\mathrm{mGlu}_{2}$ homomers are present, it could eventually contribute to signaling differences induced downstream of heteromic receptors when specific modulators are used.

The ability of all of the $\mathrm{mGlu}_{2}$ PAMs used here to retain some potentiation of glutamate and LY379268 indicates that these com- 
pounds may not be useful as selective probes for differentiating homomeric versus heteromeric receptors in native systems. During the course of these studies, we also assessed the efficacy of MNI-137, a selective Group II mGlu NAM, on $\mathrm{mGlu}_{2}$ versus $\mathrm{mGlu}_{2 / 4}$ responses (Fig. 8). For these studies, we chose to use the Group II agonist DCG-IV, as LY379268 will weakly activate $\mathrm{mGlu}_{4}$ at the higher concentrations needed to assess whether any potential interaction was competitive or noncompetitive in nature. In cells expressing $\mathrm{mGlu}_{2}$ alone, increasing concentrations of MNI-137 noncompetitively antagonized activation of $\mathrm{mGlu}_{2}$ by DCG-IV, completely abolishing the response (Fig. 8A). Consistent with its previously reported selectivity profile (Hemstapat et al., 2007), MNI-137 showed no significant effect in blocking $\mathrm{L}-\mathrm{AP} 4$ responses in cells expressing $\mathrm{mGlu}_{4}$ alone (Fig. $8 B$ ). In $\mathrm{mGlu}_{2 / 4}$ cells, MNI-137 was still able to antagonize DCG-IV responses in a noncompetitive manner (Fig. $8 C)$. Analysis using the operational model of allosterism suggested that the affinity of MNI-137 was slightly higher in $\mathrm{mGlu}_{2 / 4}$ cells. In addition, MNI-137 demonstrates increased cooperativity for affinity modulation but decreased cooperativity for efficacy modulation at $\mathrm{mGlu}_{2 / 4}$ (Table 4), evidenced by an inability to completely abolish the response to DCG-IV. Surprisingly, MNI-137 was also able to noncompetitively block activation of the $\mathrm{mGlu}_{4}$ subunit induced by stimulation with L-AP4, further supporting a structural and functional intersubunit interaction within the $\mathrm{mGlu}_{2 / 4}$ complex and suggesting that MNI-137 binding to $\mathrm{mGlu}_{2}$ can negatively modulate the function of $\mathrm{mGlu}_{4}$. Because MNI-137 does not block responses to L-AP4 unless $\mathrm{mGlu}_{2}$ is coexpressed with $\mathrm{mGlu}_{4}$, this NAM provides an excellent tool to evaluate responses to L-AP4 that may be mediated by $\mathrm{mGlu}_{2 / 4}$ in native systems.

\section{Unlike PHCCC, VU0155041 potentiates $\mathrm{mGlu}_{4}$ activity to} decrease eEPSP amplitude at corticostriatal synapses

The unique pharmacology of VU0155041 and MNI-137 on $\mathrm{mGlu}_{2 / 4}$-elicited responses suggests that these compounds provide a pair of tool compounds that can be used to provide evidence for the existence of $\mathrm{mGlu}_{2 / 4}$ heteromers in native systems, such as corticostriatal synapses. Treatment of slices with $10 \mu \mathrm{M}$ VU0155041, followed by the coaddition of $10 \mu \mathrm{M}$ VU0155041 and $500 \mathrm{nM} \mathrm{L-AP4}$, resulted in a robust decrease in the EPSP amplitude $(51.3 \pm 4.0 \%$ of baseline; Fig. $9 A)$ relative to that observed with $500 \mathrm{nM} \mathrm{L-AP} 4$ alone $(90.5 \pm 6.2 \%$ of baseline; Fig. 1). These results, together with the lack of efficacy of PHCCC at the corticostriatal synapse, suggest that, in a native system, the potentiation of the L-AP4 responses by $\mathrm{mGlu}_{4}$ PAMs mimics the differential responses observed in cells coexpressing $\mathrm{mGlu}_{2}$ and $\mathrm{mGlu}_{4}$. Furthermore, these results suggest that homomeric $\mathrm{mGlu}_{4}$ receptors, which would be predicted to respond to PHCCC, are expressed at extremely low abundance, if at all, in these synaptic terminals.

If $\mathrm{mGlu}_{2 / 4}$ heteromeric receptors play a dominant role in regulating transmission at corticostriatal synapses, we would also
B

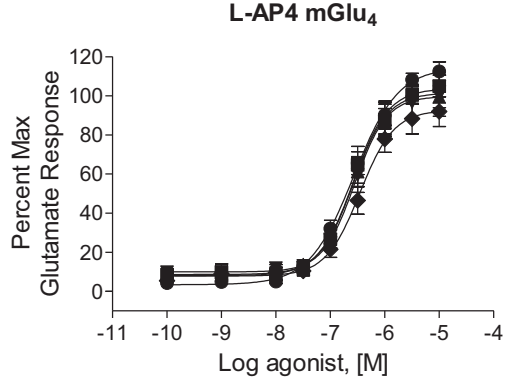

D

L-AP4 mGlu $2 / 4$

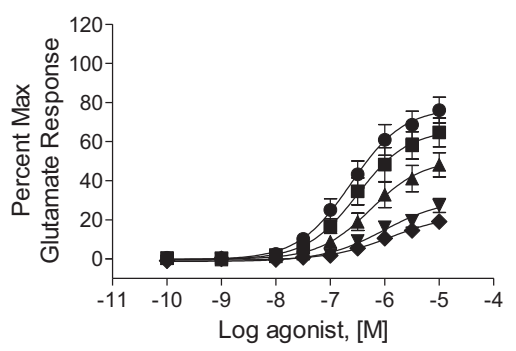

Figure 8. MNI-137 exhibits reduced efficacy when $\mathrm{mGlu}_{4}$ and $\mathrm{mGlu}_{2}$ are coexpressed and noncompetitively antagonizes thallium flux was measured as described, and responses were normalized to the maximal response induced by $1 \mathrm{~mm}$ glutamate in each individual cell line. All values represent mean $\pm \operatorname{SEM}(n=3)$.

Table 4. MNI-137 exhibits enhanced affinity but decreased efficacy in modulating DCV-IV responses in $\mathrm{mGlu}_{2 / 4}$ cells compared with cells expressing $\mathrm{mGlu}_{2}$ alone $^{a}$

\begin{tabular}{lll}
\hline Parameters & $\mathrm{mGlu}_{2}$ & $\mathrm{mGlu}_{2 / 4}$ \\
\hline $\log \mathrm{KB}$ & $-6.82 \pm 0.04$ & $-7.18 \pm 0.03^{b}$ \\
$\log \alpha$ & $-0.47 \pm 0.05$ & $-0.74 \pm 0.05^{c}$ \\
$\log \beta$ & -100 & $-0.69 \pm 0.04$ \\
\hline
\end{tabular}

${ }^{a}$ Data were analyzed using the operational model of allosterism as described in Materials and Methods. The $\log _{\mathrm{A}}$ of DCG-IV for mGlu 2 was set to -6.959 according to literature values; $\log \tau_{\mathrm{B}}$ was set to -100 . Data represent the mean \pm SEM of three independent experiments performed in duplicate. $p$ values (unpaired Student's $t$ test; $n \geq 3$, two-tailed).

${ }^{b} p=0.0028$ between $\mathrm{mGlu} \mathrm{u}_{2}$ cells and $\mathrm{mGlu} \mathrm{u}_{2 / 4}$ cells.

$c_{p}=0.0206$ between $m \mathrm{mGlu}_{2}$ cells and $\mathrm{mGlu}_{2 / 4}$ cells.

predict that the $\mathrm{mGlu}_{2}$ and $\mathrm{mGlu}_{2 / 4}$ NAM MNI-137 would inhibit the effect of L-AP4 at this synapse. Treatment of slices with L-AP4 $(100 \mu \mathrm{M})$ robustly inhibited the amplitude of electrically eEPSPs in striatal medium spiny neurons $(62.3 \pm 4.8 \%$ of baseline; Fig. 9C). Bath application of MNI-137 (10 $\mu \mathrm{M})$ for $10 \mathrm{~min}$ produced a small increase in EPSP amplitude (112.7 $\pm 3.5 \%$ of baseline, Fig. 9D). After pretreatment with MNI-137, $10 \mathrm{~min}$ bath application of $100 \mu \mathrm{M}$ L-AP4, in combination with MNI-137, returned EPSP amplitudes to baseline values (100.1 $\pm 3.4 \%$ of baseline; Fig. 9D) and produced significantly less inhibition of EPSP amplitude compared with L-AP4 alone. The average inhibition of EPSP amplitude for L-AP4 alone was 37.1 $\pm 5.8 \%$, whereas the L-AP4-induced inhibition of EPSP amplitude after MNI-137 treatment was only $12.5 \pm 2.7 \%(p<0.05$, unpaired $t$ test; Fig. 9E). These results indicate that an $\mathrm{mGlu}_{2} \mathrm{NAM}$ can regulate the responses of an $\mathrm{mGlu}_{4}$ agonist at corticostriatal synapses, providing additional evidence for $\mathrm{mGlu}_{2 / 4}$ heteromer expression in vivo. 
A

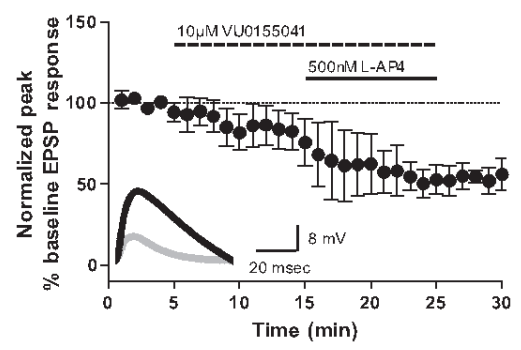

C

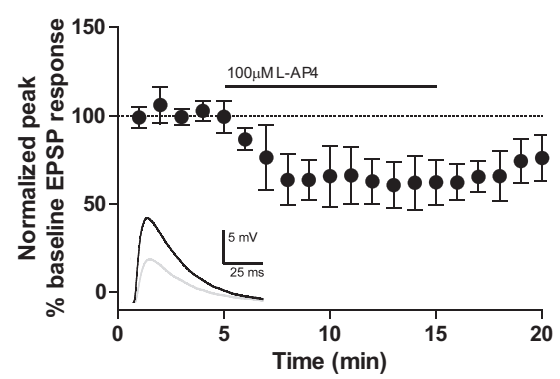

E

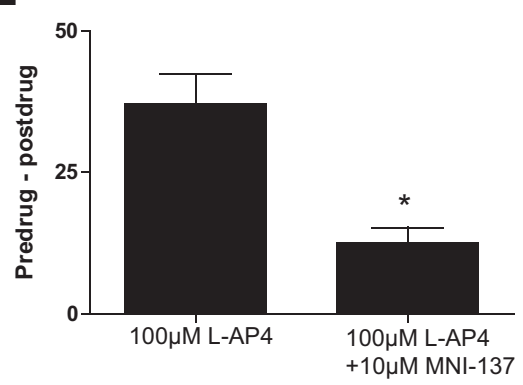

Figure 9. VU0155041 and MNI-137 exhibit unique pharmacology at corticostriatal synapses. EPSPs were recorded in medium spiny neurons after stimulation of the white matter between the cortex and striatum with a bipolar electrode. All compounds were bath applied. Data are normalized to the average baseline EPSP amplitude. Insets, Sample traces from an individual experiment. Black represents averaged traces from minute before L-AP4 application; gray represents averaged traces from last minute of L-AP4 application. $\boldsymbol{A}, \boldsymbol{B}$, Slices were treated with $10 \mu \mathrm{m}$ VU0155041 followed by coapplication of $10 \mu \mathrm{m}$ VU0155041 and $500 \mathrm{nM} \mathrm{L-AP4}$. Two slices exhibited responses when VU0155041 was applied alone. Solid and dashed lines indicate time of compound additions $(\boldsymbol{A})$. Bar graphs summarizing the normalized peak EPSP response measured during the last 2 min of compound addition (B). Values represent mean \pm SEM $(n=5) .{ }^{*} p<0.05$, compared with 500 nM L-AP4 using Dunnett's multiple-comparison test. $\boldsymbol{C}-\boldsymbol{E}$, Slices were treated with $100 \mu \mathrm{m}$ L-AP4 alone ( $\boldsymbol{C}$ or after a 10 min pretreatment with $10 \mu \mathrm{m}$ MNI-137 (D). The difference between EPSP amplitudes during the minute before L-AP4 application and the last minute of L-AP4 application were calculated for each cell, and the average difference for each treatment group is shown in $\boldsymbol{E}$. Data represent mean $\pm \operatorname{SEM}(n=5-7)$. ${ }^{*} p<0.05$ (unpaired $t$ test).

\section{Discussion}

As recombinant cell lines are used to identify and characterize allosteric reagents, it is important to recognize potential discrepancies between in vitro and in vivo properties of these novel compounds. For example, MMPIP, an allosteric antagonist of $\mathrm{mGlu}_{7}$, inhibits $\mathrm{mGlu}_{7}$ activity in recombinant cell lines (Mitsukawa et al., 2005; Suzuki et al., 2007; Niswender et al., 2010); however, when applied to brain slices, it fails to inhibit $\mathrm{mGlu}_{7}$-mediated L-AP4 responses at SC-CA1 synapses (Niswender et al., 2010). We show here that PHCCC fails to potentiate $\mathrm{mGlu}_{4}$ at corticostriatal synapses, despite its well-established efficacy in vitro and at other synapses. These data suggest that the activity of allosteric compounds may be dramatically altered by the in vivo environment, such as differences in expression of signaling pathway components or variations in receptor assembly.

Our data presented here demonstrate $\mathrm{mGlu}_{2 / 4}$ interaction in native rodent tissue. The detection of $\mathrm{mGlu}_{2 / 4}$ interactions in dorsal striatum is consistent with electrophysiology data that both $\mathrm{mGlu}_{2}$ and $\mathrm{mGlu}_{4}$ act presynaptically to reduce excitatory transmission at corticostriatal synapses (Johnson et al., 2005; Bennouar et al., 2013), although $\mathrm{mGlu}_{2}$ and $\mathrm{mGlu}_{4}$ may also colocalize on other striatal axon terminals. Similarly, medial prefrontal cortex samples contain many axon terminals where $\mathrm{mGlu}_{2}$ and $\mathrm{mGlu}_{4}$ might colocalize. Although we cannot conclude the precise localization of $\mathrm{mGlu}_{2 / 4}$ heteromers in this region, physiological evidence suggests that presynaptic expression of $\mathrm{mGlu}_{2}$ and $\mathrm{mGlu}_{4}$ at thalamocortical synapses (Marek et al., 2000; Benneyworth et al., 2007; Zhang and Marek, 2007) is also a potential source of $\mathrm{mGlu}_{2 / 4}$ hetero-complexes.

We observed altered efficacies of $\mathrm{mGlu}_{4}$ and $\mathrm{mGlu}_{2}$ PAMs in cells coexpressing $\mathrm{mGlu}_{2}$ and $\mathrm{mGlu}_{4}$ (Fig. 6; Table 2 ), consistent with a previous report (Kammermeier, 2012). Modeling of $\mathrm{mGlu}_{4}$ PAM interactions using the operational model of allosterism suggests that binding to two distinct allosteric pockets results in differential pharmacological profile changes with regards to affinity and cooperativity. This suggests that these allosteric binding pockets may encounter differential conformation changes upon heterointeraction of the two receptor subunits, although more detailed structural studies are needed.

In our experiments, $\mathrm{mGlu}_{2}$ and $\mathrm{mGlu}_{4}$ were cotransfected without being forced to form an interaction. Advantages of this approach are that it avoids tagging of the receptors, which may affect pharmacology, and that it more closely mimics the receptor assembly in an in vivo environment where mGlu homomers and heteromers may coexist. At the receptor levels expressed in our stable cell lines, the pharmacology of orthosteric agonists, such as LY379268 and L-AP4, was not dramatically altered (Fig. 4). However, although both agonists elicited a response alone, the Hill slopes of the concentration-response curves were significantly decreased compared with cells expressing a single mGlu subtype, suggesting an interaction between the subunits. We did observe differences in the ability of LY379268 and L-AP4 to achieve maximal responses (LY379268 was a full agonist, whereas L-AP4 only achieved a $70 \%$ maximal response), which could result from $\mathrm{mGlu}_{2}$ homodimers under these experimental conditions. In contrast, our data appear to be consistent with little to no expres- 
sion of $\mathrm{mGlu}_{4}$ homodimers in our $\mathrm{mGlu}_{2 / 4}$ cell line. For example, the fact that PHCCC and 4PAM-2 exhibit significantly decreased/no efficacy in potentiating L-AP4 responses suggests that most $\mathrm{mGlu}_{4}$ subunits in $\mathrm{mGlu}_{2 / 4}$ cell line appear to be in a complexed form. Although we cannot definitively conclude that the receptors are forming strict heterodimers (as opposed to oligomers) in our system, the work of Doumazane et al. (2011) suggests that $\mathrm{mGlu}_{2}$ and $\mathrm{mGlu}_{4}$ form heterodimers, rather than higherorder oligomers, in vitro.

To overcome the caveat of $\mathrm{mGlu}_{2}$ homodimers in the stable cell line, we performed transient transfection experiments with a constant amount of $\mathrm{mGlu}_{4}$ or $\mathrm{mGlu}_{7}$ and variable amounts of $\mathrm{mGlu}_{2}$. Results from these studies suggest that expression of $\mathrm{mGlu}_{4}$ specifically results in changes in the potency and cooperativity of an $\mathrm{mGlu}_{2}$ orthosteric agonist, and that alterations in $\mathrm{mGlu}_{4}$ PAM pharmacology are dependent on the amount of $\mathrm{mGlu}_{2}$ coexpression. Quite strikingly, one-tenth of the amount of $\mathrm{mGlu}_{2}$ compared with $\mathrm{mGlu}_{4}$ resulted in a nearly complete loss of potentiation of the glutamate response by PHCCC and 4PAM-2, suggesting that the hetero-interactions may be dominant in terms of $\mathrm{mGlu}_{4}$. We would note that, when $\mathrm{mGlu}_{2}$ and $\mathrm{mGlu}_{4}$ were cotransfected in similar amounts, the potency and Hill slope of the LY379268 response were the same as when $\mathrm{mGlu}_{2}$ is expressed alone. The lack of effect of PHCCC and 4-PAM2, along with the similarities in Hill slope and potency once the amount of $\mathrm{mGlu}_{2}$ equals that of $\mathrm{mGlu}_{4}$, suggests that the interpretation that there are homomeric pools of $\mathrm{mGlu}_{2}$ and heteromeric $\mathrm{mGlu}_{2 / 4}$ under these conditions is most consistent with the current data. These data also recapitulate Kammermeier's (2012) finding that $\mathrm{mGlu}_{2}$ homodimers existed when $\mathrm{mGlu}_{2}$ and $\mathrm{mGlu}_{4}$ were transfected with a 1:1 ratio but not a 1:3 ratio.

It has previously been shown that heterodimerization/heterointeractions of receptors can substantially alter the effect of pharmacological reagents. For example, González-Maeso et al. (2008) reported that $5-\mathrm{HT}_{2 \mathrm{~A}}$ receptors interact with $\mathrm{mGlu}_{2}$ and form functional complexes in cerebral cortex. In the presence of this $5-\mathrm{HT}_{2 \mathrm{~A}} / \mathrm{mGlu}_{2}$ complex, hallucinogenic $5-\mathrm{HT}_{2 \mathrm{~A}}$ agonists triggered unique cellular responses, which may contribute to the pathogenesis of psychosis. The combination of unique orthosteric and allosteric ligands for $\mathrm{mGlu}_{2}$ and $\mathrm{mGlu}_{4}$ now allows us to pharmacologically interrogate the functional expression of $\mathrm{mGlu}_{4}$-containing heteromers at synapses in the CNS. For example, we found that VU0155041 potentiated L-AP4 responses at corticostriatal synapses, whereas PHCCC, which binds to a distinct allosteric site, showed no effect (Figs. 1 and 9). In addition, the $\mathrm{mGlu}_{2}$ NAM MNI-137 blocked L-AP4-induced responses at the corticostriatal synapse, recapitulating the pharmacological profile of this compound in the $\mathrm{mGlu}_{2 / 4}$ cell line.

Although the results reported here cannot be seen as definitive evidence of $\mathrm{mGlu}_{2 / 4}$ heterodimer formation in the CNS and could be explained by other potential mechanisms, such as involvement of other partner proteins, multiple lines of evidence are consistent with functional existence of predominantly $\mathrm{mGlu}_{2 / 4}$ heteromers at corticostriatal synapses: (1) time-resolved FRET studies by Doumazane et al. (2011) indicate that $\mathrm{mGlu}_{2}$ and $\mathrm{mGlu}_{4}$ form strict heterodimers when expressed in the same cells; (2) coimmunoprecipitation data using rodent striatal tissue demonstrate some type of physical interaction between $\mathrm{mGlu}_{2}$ and $\mathrm{mGlu}_{4}$ in this brain region; and (3) pharmacological properties at corticostriatal synapses recapitulate the results seen in the $\mathrm{mGlu}_{2 / 4}$ recombinant cells. Regardless of mechanism, these studies provide compelling evidence that the function of mGlu receptors can be context-dependent and that $\mathrm{mGlu}_{4}$ may display fundamentally distinct responses to selective allosteric modulators at different synapses.

Interestingly, both PHCCC and VU0155041 have been shown to reverse reserpine-induced akinesia in rodents, suggesting that the anti-parkinsonian effects by $\mathrm{mGlu}_{4}$ PAMs may not be dependent on their activity at corticostriatal synapses. However, corticostriatal synapses have been shown to be overactive in dopamine-depleted animals (Picconi et al., 2004; Centonze et al., 2005), which contributes to the loss of spines of striatal medium spiny neurons in PD (Garcia et al., 2010). The work of Picconi et al. demonstrates that dysregulated plasticity at these synapses, such as long-term depression and depotentiation, may underlie the mechanism of L-DOPA-induced dyskinesia (Picconi et al., 2003, 2011). Therefore, $\mathrm{mGlu}_{4}$ PAMs that potentiate $\mathrm{mGlu}_{4}$ containing heteromers may potentially provide additional therapeutic benefits, such as restoring morphology of striatal neurons and reversing L-DOPA-induced dyskinesias. In contrast, PAMs with selectivity for homodimers over heteromers might be beneficial for targeting $\mathrm{mGlu}_{4}$ activation in regions predominantly expressing $\mathrm{mGlu}_{4}$ alone if activation of heteromers proves to engender side effects.

Our findings also indicate that a reevaluation of the impact of mGlu receptor hetero-interactions on physiological function and receptor pharmacology is warranted. In this manuscript, we specifically focused on the heteromers comprised of $\mathrm{mGlu}_{2}$ and $\mathrm{mGlu}_{4}$, as these receptors strongly interact in cell lines (Doumazane et al., 2011); additionally, the overlapping expression patterns of $\mathrm{mGlu}_{2}$ and $\mathrm{mGlu}_{4}$ in the CNS, as well as the abundant selective orthosteric and allosteric ligands available for each of the two subtypes, also makes $\mathrm{mGlu}_{2 / 4}$ an attractive combination to explore. However, beyond $\mathrm{mGlu}_{2 / 4}$, other combinations of $\mathrm{mGlu}$ subtypes are colocalized in the CNS as well. For instance, $\mathrm{mGlu}_{4}$ and $\mathrm{mGlu}_{8}$ are coexpressed at the lateral olfactory tractpiriform cortex synapse and suppress synaptic transmission (Jones et al., 2008). $\mathrm{mGlu}_{1}$ and $\mathrm{mGlu}_{5}$ are coexpressed in several neuronal populations, including CA1 hippocampal pyramidal cells, striatal cholinergic interneurons, STN glutamatergic neurons, and SNr GABAergic neurons (for review, see Valenti et al., 2002). In addition, both $\mathrm{mGlu}_{7}$ and $\mathrm{mGlu}_{8}$ receptors modulate the Schaffer collateral-CA1 synapse in neonatal rats (Ayala et al., 2008). Although the assembly of other mGlu heteromers has yet to be determined in vivo, previous studies showing aberrant activity of mGlu-selective compounds may eventually be explained by heteromer-specific pharmacology (Ayala et al., 2008; Niswender et al., 2010). As characterization of other combinations of mGlu heteromers are underway, localizing mGlu homomers and heteromers will help elucidate the complexity of mGlu receptor signaling and function and eventually contribute to rational development of therapeutic reagents that target specific tissues through selective modulation of individual receptor assemblies.

\section{References}

Ayala JE, Niswender CM, Luo Q, Banko JL, Conn PJ (2008) Group III mGluR regulation of synaptic transmission at the SC-CA1 synapse is developmentally regulated. Neuropharmacology 54:804-814. CrossRef Medline

Battaglia G, Busceti CL, Molinaro G, Biagioni F, Traficante A, Nicoletti F, Bruno V (2006) Pharmacological activation of mGlu4 metabotropic glutamate receptors reduces nigrostriatal degeneration in mice treated with 1-methyl-4-phenyl-1,2,3,6-tetrahydropyridine. J Neurosci 26:72227229. CrossRef Medline

Benneyworth MA, Xiang Z, Smith RL, Garcia EE, Conn PJ, Sanders-Bush E (2007) A selective positive allosteric modulator of metabotropic glutamate receptor subtype 2 blocks a hallucinogenic drug model of psychosis. Mol Pharmacol 72:477-484. CrossRef Medline 
Bennouar KE, Uberti MA, Melon C, Bacolod MD, Jimenez HN, Cajina M, Kerkerian-Le Goff L, Doller D, Gubellini P (2013) Synergy between L-DOPA and a novel positive allosteric modulator of metabotropic glutamate receptor 4: implications for Parkinson's disease treatment and dyskinesia. Neuropharmacology 66:158-169. CrossRef Medline

Bradley SR, Standaert DG, Rhodes KJ, Rees HD, Testa CM, Levey AI, Conn PJ (1999) Immunohistochemical localization of subtype 4a metabotropic glutamate receptors in the rat and mouse basal ganglia. J Comp Neurol 407:33-46. CrossRef Medline

Centonze D, Gubellini P, Rossi S, Picconi B, Pisani A, Bernardi G, Calabresi P, Baunez C (2005) Subthalamic nucleus lesion reverses motor abnormalities and striatal glutamatergic overactivity in experimental parkinsonism. Neuroscience 133:831-840. CrossRef Medline

Corti C, Aldegheri L, Somogyi P, Ferraguti F (2002) Distribution and synaptic localisation of the metabotropic glutamate receptor 4 (mGluR4) in the rodent CNS. Neuroscience 110:403-420. CrossRef Medline

Doumazane E, Scholler P, Zwier JM, Trinquet E, Rondard P, Pin JP (2011) A new approach to analyze cell surface protein complexes reveals specific heterodimeric metabotropic glutamate receptors. FASEB J 25:66-77. CrossRef Medline

Drolet R, Tugusheva K, Liverton N, Vogel R, Reynolds IJ, Hess FJ, Renger JJ, Kern JT, Celanire S, Tang L, Poli S, Campo B, Bortoli J, D'Addona D (2011) Binding property characterization of a novel mGluR4 positive allosteric modulator. In: Society for Neuroscience. Washington, DC: 2011 Neuroscience Meeting Planner.

Galici R, Jones CK, Hemstapat K, Nong Y, Echemendia NG, Williams LC, de Paulis T, Conn PJ (2006) Biphenyl-indanone A, a positive allosteric modulator of the metabotropic glutamate receptor subtype 2, has antipsychotic- and anxiolytic-like effects in mice. J Pharmacol Exp Ther 318:173-185. CrossRef Medline

Garcia BG, Neely MD, Deutch AY (2010) Cortical regulation of striatal medium spiny neuron dendritic remodeling in parkinsonism: modulation of glutamate release reverses dopamine depletion-induced dendritic spine loss. Cereb Cortex 20:2423-2432. CrossRef Medline

González-Maeso J, Ang RL, Yuen T, Chan P, Weisstaub NV, López-Giménez JF, Zhou M, Okawa Y, Callado LF, Milligan G, Gingrich JA, Filizola M, Meana JJ, Sealfon SC (2008) Identification of a serotonin/glutamate receptor complex implicated in psychosis. Nature 452:93-97. CrossRef Medline

Hemstapat K, Da Costa H, Nong Y, Brady AE, Luo Q, Niswender CM, Tamagnan GD, Conn PJ (2007) A novel family of potent negative allosteric modulators of Group II metabotropic glutamate receptors. J Pharmacol Exp Ther 322:254-264. CrossRef Medline

Johnson MP, Baez M, Jagdmann GE Jr, Britton TC, Large TH, Callagaro DO, Tizzano JP, Monn JA, Schoepp DD (2003) Discovery of allosteric potentiators for the metabotropic glutamate 2 receptor: synthesis and subtype selectivity of $N$-(4-(2-methoxyphenoxy)phenyl)- $N$-(2,2,2trifluoroethylsulfonyl)pyrid-3-ylmethylamine. J Med Chem 46:31893192. CrossRef Medline

Johnson MP, Barda D, Britton TC, Emkey R, Hornback WJ, Jagdmann GE, McKinzie DL, Nisenbaum ES, Tizzano JP, Schoepp DD (2005) Metabotropic glutamate 2 receptor potentiators: receptor modulation, frequencydependent synaptic activity, and efficacy in preclinical anxiety and psychosis model(s). Psychopharmacology (Berl) 179:271-283. CrossRef Medline

Jones PJ, Xiang Z, Conn PJ (2008) Metabotropic glutamate receptors mGluR4 and mGluR8 regulate transmission in the lateral olfactory tractpiriform cortex synapse. Neuropharmacology 55:440-446. CrossRef Medline

Kammermeier PJ (2012) Functional and pharmacological characteristics of metabotropic glutamate receptors 2/4 heterodimers. Mol Pharmacol 82: 438-447. CrossRef Medline

Kunishima N, Shimada Y, Tsuji Y, Sato T, Yamamoto M, Kumasaka T, Nakanishi S, Jingami H, Morikawa K (2000) Structural basis of glutamate recognition by a dimeric metabotropic glutamate receptor. Nature 407: 971-977. CrossRef Medline

Leach K, Sexton PM, Christopoulos A (2007) Allosteric GPCR modulators: taking advantage of permissive receptor pharmacology. Trends Pharmacol Sci 28:382-389. CrossRef Medline

Maj M, Bruno V, Dragic Z, Yamamoto R, Battaglia G, Inderbitzin W, Stoehr N, Stein T, Gasparini F, Vranesic I, Kuhn R, Nicoletti F, Flor PJ (2003) (-)-PHCCC, a positive allosteric modulator of mGluR4: characteriza- tion, mechanism of action, and neuroprotection. Neuropharmacology 45:895-906. CrossRef Medline

Marek GJ, Wright RA, Schoepp DD, Monn JA, Aghajanian GK (2000) Physiological antagonism between 5-hydroxytryptamine(2A) and Group II metabotropic glutamate receptors in prefrontal cortex. J Pharmacol Exp Ther 292:76-87. Medline

Marino MJ, Williams DL Jr, O’Brien JA, Valenti O, McDonald TP, Clements MK, Wang R, DiLella AG, Hess JF, Kinney GG, Conn PJ (2003) Allosteric modulation of Group III metabotropic glutamate receptor 4: a potential approach to Parkinson's disease treatment. Proc Natl Acad Sci U S A 100:13668-13673. CrossRef Medline

Mitsukawa K, Yamamoto R, Ofner S, Nozulak J, Pescott O, Lukic S, Stoehr N, Mombereau C, Kuhn R, McAllister KH, van der Putten H, Cryan JF, Flor PJ (2005) A selective metabotropic glutamate receptor 7 agonist: activation of receptor signaling via an allosteric site modulates stress parameters in vivo. Proc Natl Acad Sci U S A 102:18712-18717. CrossRef Medline

Monastyrskaia K, Lundstrom K, Plahl D, Acuna G, Schweitzer C, Malherbe P, Mutel V (1999) Effect of the umami peptides on the ligand binding and function of rat mGlu4a receptor might implicate this receptor in the monosodium glutamate taste transduction. Br J Pharmacol 128:10271034. CrossRef Medline

Neki A, Ohishi H, Kaneko T, Shigemoto R, Nakanishi S, Mizuno N (1996) Pre- and postsynaptic localization of a metabotropic glutamate receptor, mGluR2, in the rat brain: an immunohistochemical study with a monoclonal antibody. Neurosci Lett 202:197-200. CrossRef Medline

Niswender CM, Conn PJ (2010) Metabotropic glutamate receptors: physiology, pharmacology, and disease. Annu Rev Pharmacol Toxicol 50:295322. CrossRef Medline

Niswender CM, Johnson KA, Luo Q, Ayala JE, Kim C, Conn PJ, Weaver CD (2008a) A novel assay of Gi/o-linked G protein-coupled receptor coupling to potassium channels provides new insights into the pharmacology of the Group III metabotropic glutamate receptors. Mol Pharmacol 73: 1213-1224. CrossRef Medline

Niswender CM, Johnson KA, Weaver CD, Jones CK, Xiang Z, Luo Q, Rodriguez AL, Marlo JE, de Paulis T, Thompson AD, Days EL, Nalywajko T, Austin CA, Williams MB, Ayala JE, Williams R, Lindsley CW, Conn PJ (2008b) Discovery, characterization, and antiparkinsonian effect of novel positive allosteric modulators of metabotropic glutamate receptor 4. Mol Pharmacol 74:1345-1358. CrossRef Medline

Niswender CM, Johnson KA, Miller NR, Ayala JE, Luo Q, Williams R, Saleh S, Orton D, Weaver CD, Conn PJ (2010) Context-dependent pharmacology exhibited by negative allosteric modulators of metabotropic glutamate receptor 7. Mol Pharmacol 77:459-468. CrossRef Medline

Ohishi H, Shigemoto R, Nakanishi S, Mizuno N (1993) Distribution of the messenger RNA for a metabotropic glutamate receptor, mGluR2, in the central nervous system of the rat. Neuroscience 53:1009-1018. CrossRef Medline

Ohishi H, Akazawa C, Shigemoto R, Nakanishi S, Mizuno N (1995) Distributions of the mRNAs for L-2-amino-4-phosphonobutyrate-sensitive metabotropic glutamate receptors, mGluR4 and mGluR7, in the rat brain. J Comp Neurol 360:555-570. CrossRef Medline

Picconi B, Pisani A, Centonze D, Battaglia G, Storto M, Nicoletti F, Bernardi G, Calabresi P (2002) Striatal metabotropic glutamate receptor function following experimental parkinsonism and chronic levodopa treatment. Brain 125:2635-2645. CrossRef Medline

Picconi B, Centonze D, Håkansson K, Bernardi G, Greengard P, Fisone G, Cenci MA, Calabresi P (2003) Loss of bidirectional striatal synaptic plasticity in L-DOPA-induced dyskinesia. Nat Neurosci 6:501-506. CrossRef Medline

Picconi B, Centonze D, Rossi S, Bernardi G, Calabresi P (2004) Therapeutic doses of L-dopa reverse hypersensitivity of corticostriatal D2-dopamine receptors and glutamatergic overactivity in experimental parkinsonism. Brain 127:1661-1669. CrossRef Medline

Picconi B, Bagetta V, Ghiglieri V, Paillè V, Di Filippo M, Pendolino V, Tozzi A, Giampà C, Fusco FR, Sgobio C, Calabresi P (2011) Inhibition of phosphodiesterases rescues striatal long-term depression and reduces levodopa-induced dyskinesia. Brain 134:375-387. CrossRef Medline

Pisani A, Calabresi P, Centonze D, Bernardi G (1997) Activation of Group III metabotropic glutamate receptors depresses glutamatergic transmission at corticostriatal synapse. Neuropharmacology 36:845851. CrossRef Medline 
Romano C, Yang WL, O’Malley KL (1996) Metabotropic glutamate receptor 5 is a disulfide-linked dimer. J Biol Chem 271:28612-28616. CrossRef Medline

Schweitzer C, Kratzeisen C, Adam G, Lundstrom K, Malherbe P, Ohresser S, Stadler H, Wichmann J, Woltering T, Mutel V (2000) Characterization of [(3)H]-LY354740 binding to rat mGlu2 and mGlu3 receptors expressed in $\mathrm{CHO}$ cells using semliki forest virus vectors. Neuropharmacology 39:1700-1706. CrossRef Medline

Suzuki G, Tsukamoto N, Fushiki H, Kawagishi A, Nakamura M, Kurihara H, Mitsuya M, Ohkubo M, Ohta H (2007) In vitro pharmacological characterization of novel isoxazolopyridone derivatives as allosteric metabotropic glutamate receptor 7 antagonists. J Pharmacol Exp Ther 323: 147-156. CrossRef Medline

Valenti O, Conn PJ, Marino MJ (2002) Distinct physiological roles of the
Gq-coupled metabotropic glutamate receptors co-expressed in the same neuronal populations. J Cell Physiol 191:125-137. CrossRef Medline

Valenti O, Marino MJ, Wittmann M, Lis E, DiLella AG, Kinney GG, Conn PJ (2003) Group III metabotropic glutamate receptor-mediated modulation of the striatopallidal synapse. J Neurosci 23:7218-7226. Medline

Valenti O, Mannaioni G, Seabrook GR, Conn PJ, Marino MJ (2005) Group III metabotropic glutamate-receptor-mediated modulation of excitatory transmission in rodent substantia nigra pars compacta dopamine neurons. J Pharmacol Exp Ther 313:1296-1304. CrossRef Medline

Zhang C, Marek GJ (2007) Group III metabotropic glutamate receptor agonists selectively suppress excitatory synaptic currents in the rat prefrontal cortex induced by 5 -hydroxytryptamine2A receptor activation. J Pharmacol Exp Ther 320:437-447. CrossRef Medline 